Article

\title{
Development of a Natural Anti-Age Ingredient Based on Quercus pubescens Willd. Leaves Extract-A Case Study
}

\author{
Hortense Plainfossé ${ }^{1,2,3}$, Pauline Burger ${ }^{1}$, Stéphane Azoulay ${ }^{2}$, Anne Landreau ${ }^{2,4}$, \\ Grégory Verger-Dubois ${ }^{1,3}$ and Xavier Fernandez ${ }^{2, *}$ \\ 1 NissActive, Pépinière Innovagrasse, Espace Jacques-Louis Lions, 4 traverse Dupont, 06130 Grasse, France; \\ hortense.plainfosse@nissactive.com (H.P.); pauline.burger@nissactive.com (P.B.); \\ gvd@nissactive.com (G.V.-D.) \\ 2 Université Côte d'Azur, CNRS, Institut de Chimie de Nice UMR7272, 06108 Nice, France; \\ stephane.azoulay@unice.fr (S.A.); anne.landreau@unice.fr (A.L.) \\ 3 Laboratoires JYTA, 1ère Avenue, 5ème rue, 06156 Carros CEDEX, France \\ 4 Faculté de Santé, Université d'Angers, 16 Boulevard Daviers, 49045 Angers CEDEX 01, France \\ * Correspondence: Xavier.Fernandez@unice.fr; Tel.: +33-4-9207-6469
}

Received: 22 December 2017; Accepted: 17 January 2018; Published: 27 January 2018

\begin{abstract}
Consumers pay more and more attention not just to the safety and health aspects of ingredients entering their cosmetics' formulations, but also to their potency, origin, processing, ethical value and environmental footprint. Sustainability of the supply chain, preservation of biodiversity, as well as greener extraction techniques are hence very popular with consumers. Consumers are primarily concerned by the efficacy of the cosmetic products they use and continuously scrutinize product labels, so marketing arguments need to be based on rigorous testing and reliable results to support claims (anti-age, anti-pollution, etc.) displayed on the product's packaging. As a result, the increasing demand for natural ingredients with assessed bioactivities has profoundly modified the strategies adopted by cosmetic professionals to innovate in terms of actives. Sourcing and developing new natural cosmetic actives is a long-term procedure that is thoroughly described in the present paper, via the example of the design of both liquid and solid ingredients based on Quercus pubescens Willd. leaves extract, for which anti-age properties were assessed by a combination of in vitro assays.
\end{abstract}

Keywords: natural cosmetic ingredient; Quercus pubescens Willd.; truffle oak; anti-age; cosmetic bioassays; flavonoids; phenolic compounds

\section{Introduction}

Constantly evolving consumers' lifestyle is the key driver behind the transformation of the worldwide cosmetic industry engaged over the two past decades [1]: the sector is expected to reach $\$ 429.8$ billion by 2022, registering a CAGR of 4.3\% (Compound Annual Growth Rate, forecast period 2016-2022) [2]. An inclination towards natural beauty and personal care products has been initiated few years ago, fueled by the consumers' ecological and ethical considerations, and their will for safer cosmetics. 'Natural' is often, not always quite rightly, synonym of 'safer products presenting less side effects' in the consumers' mind and one notably notices the boom of 'without' claims. In brief, consumers are looking for safer and greener cosmetic ingredients and place a premium on real efficacy, so manufacturers must provide tangible evidence of the allegations claimed on the products' packaging [3,4]. Consequently, manufacturers are constantly seeking originality and naturality, while multiplying bioassays to scientifically substantiate cosmetic allegations [5], and the natural beauty market valued approximately 11.06 billion U.S. dollars worldwide in 2016, is estimated to reach almost 22 billion U.S. dollars in 2024 [6]. 
The global cosmetic ingredients market amounted to approximately 22.9 billion U.S. dollars in 2016 is expected to rise to reach 33.80 billion U.S. dollars by the end of 2025 [7,8]. Even continuously progressing, natural ingredients still represent today only $7 \%$ of the global market [9]. To keep up with current trends, cosmetic manufacturers must ceaselessly innovate and develop new natural ingredients in accordance to consumer preferences, using the latest technologies of extraction, and notably of eco-extraction (activation methods such as ultrasounds or microwaves, green solvents, etc. [10]), or exploring the potentialities of original natural resources, while keeping sustainability and ethics in mind. Manufacturers can adopt one of the two following strategies to source naturally derived ingredients: they can either call on ethnobotanical knowledge, i.e., select plants of interest based on their renown traditional use (this re-discovery of traditional herbs is particularly efficient in regions presenting such continuous practices), or based on a high-throughput screening (often preferred in more industrialized regions, where traditional practices tend to disappear) [11].

Consumers are daily exposed to air pollutants (volatile organic compounds, ozone, particulate matter, etc.) and to all kinds of blue light sources (fluorescent and LED lighting, flat-screen TV, digital devices such as smartphones, laptops, etc.). They are more and more concerned with the impact of pollution and their hectic lifestyle, on the quality and beauty of their skin [12,13]. These preoccupations are strongly setting the guidelines of the cosmetics market over the next few years: anti-pollution, anti-blue light and moreover anti-age actives will call the tune on the cosmetic ingredients' market. Skin health and beauty are intimately linked to the overall consumers' well-being, so it is not surprising that skincare constitutes the cosmetic segment that witnessed the strongest growth over the 1998-2010 period, with maket shares evolving from $16.4 \%$ to $23.0 \%$ [1]. Skin aging is a complex biological process influenced by a combination of endogenous (genetics, metabolic processes, etc.) and exogenous (pollution, UV-radiations, chemicals, etc.) factors [14,15]. To fight the visible signs of aging, cosmetic anti-aging ingredients reinforce the skin barrier, improve the skin elasticity, boost its density, protect it against radicals, fade wrinkles, diminish the apparition of age spots, etc. The pursuit of beauty and the demographic realities-life expectancy registered over the last few years its fastest gain since the 1960s [16] — are substantially and ceaselessly fueling the demand for anti-aging actives and formulations; this sector is no exception: naturality rules.

The worldwide biodiversity constitutes an exceptional reservoir of innovative molecules presenting highly diverse structures and functions that can be tapped for novel drug leads as well as cosmetic development [17]. The Mediterranean area has long been identified as a region presenting high biodiversity due to its remarkable flora and specially its high rate of endemic species: representing only $2 \%$ of the world's surface, this area houses $20 \%$ of the world's total floristic richness $[18,19]$. This Mediterranean biome hence constitutes a choice target to source interesting molecules and notably natural ingredients intended for cosmetics and personal care formulation. Due to its establishment at the heart of this rich region and to its expertise in phytochemistry, our research team has access to this diversity through longstanding collaborations. Hence, 50 Mediterranean plants were initially selected over more than 500 available at the laboratory for the present study, based on their accessibility and their originality regarding the anti-aging activity (no anteriority such as already existing scientific article or patent). Hence, aqueous and organic solvent extracts, as well as essential oils were investigated for their anti-aging properties. From this survey, a crude extract of Quercus pubescens Willd. (Fagaceae) leaves display the best unprecedented anti-aging activities and was then selected for further investigations leading to the development of an innovative anti-age active and its practical cosmetic formulation.

Q. pubescens (genus Quercus sect. Quercus), commonly known as downy or pubescent oak, is a species of white oak native to southern Europe and southwest Asia [20] ; the word 'pubescens' meaning 'with soft bristle' actually refers to its hairy leaves and twigs, constituting an adaptation to drought. This species is also known as 'truffle oak' as it serves among other species as a host for economically important truffles. Q. pubescens is a medium-sized deciduous tree growing up to $20 \mathrm{~m}$, preferentially in regions presenting a sub-Mediterranean microclimate characterized by hot dry summers and cool winters with little rainfall [21,22]. Particularly adaptable, this species grows on well-drained lime soils 
as well as on acidic grounds, and is found from sea level up to $1300 \mathrm{~m}$ [23]. Extracts of various species of oak are already used in cosmetics, mainly as skin conditioning actives; however, those actives are mainly based on bark or wood extracts: such a sampling endangers the survival of the oak trees tapped and is therefore not sustainable [24-27]. One patent reports the composition of an anti-oxidant cosmetic formula based on $Q$. robur, Q. ilex and $Q$. pubescens bark extracts [28]. To our knowledge, no previous study reports the development and the subsequent use of an extract of $Q$. pubescens leaves as a cosmetic active.

Developing and objectifying new natural cosmetic ingredients is a long-term procedure that is presented in detail in this article, via the example of the design of an anti-age ingredient based on an extract of $Q$. pubescens leaves. The first step consists of the optimization of the extraction procedure of $Q$. pubescens leaves to potentialize the bioactivity of the resulting extract while keeping in mind its further industrial scale-up. The second part of such a development encompasses the amelioration of the extract's formulability, including its discoloration and/or deodorization, and the further development of both liquid and solid forms of the cosmetic ingredient.

\section{Materials and Methods}

All chemicals were obtained from Sigma-Aldrich (St. Louis, MO, USA) unless otherwise stated.

\subsection{Plant Material}

Leaves of Q. pubescens were collected respectively in December 2016 and in June 2017 from two different places in Provence-Alpes-Côte d'Azur, France (Figure 1): Vinon-sur-Verdon and the Valrose Park in Nice. A voucher has been deposited in the botanical collection at the Natural History Museum, Nice under the reference number NICE-D-4382.

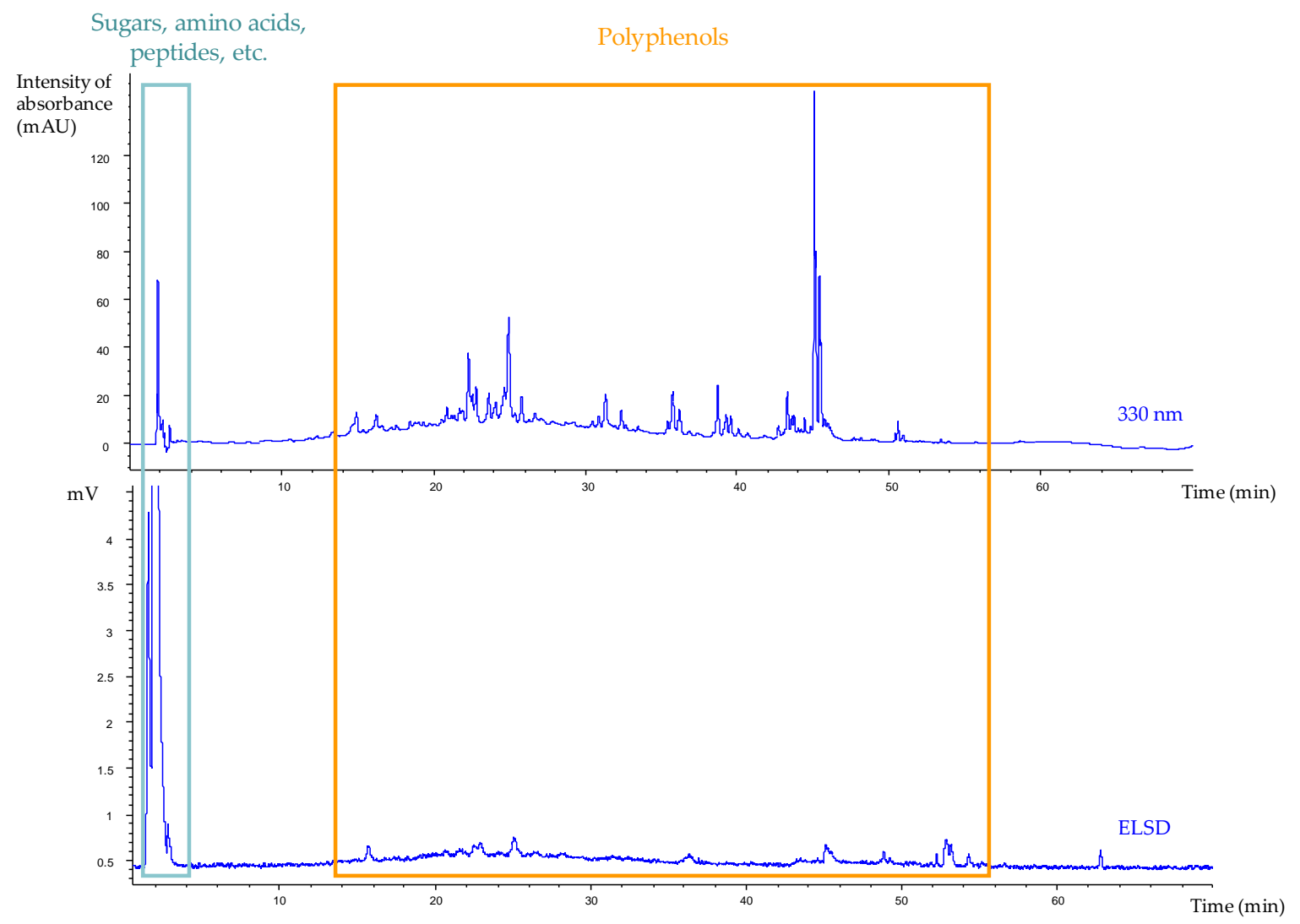

Figure 1. HPLC chromatograms obtained on a Luna ${ }^{\circledR} \mathrm{C}_{18}$ column $(150 \mathrm{~mm} \times 4.6 \mathrm{~mm} ; 5 \mu \mathrm{m})$ at $330 \mathrm{~nm}$ and with ELSD, presenting the major families of compounds identified in Oak1 extract. 


\subsection{Plant Extraction}

The plant material was air dried and crushed into fine powder. Extraction of plant material was then performed by maceration using either the water/ethanol $\left(\mathrm{H}_{2} \mathrm{O} / \mathrm{EtOH} 1 / 1\right)$ system or pure EtOH. About $1 \mathrm{~g}$ of plant material was extracted with approximately $10 \mathrm{~g}$ of solvent (extraction ratio 1/10) at room temperature (RT) using a magnetic stirrer $(500 \mathrm{rpm})$ for $2 \mathrm{~h}$. The resulting extracts were then filtered over filter paper 8-12 $\mu \mathrm{m}$, gathered together and vacuum-concentrated to dryness.

\subsection{Fractionation of $Q$. pubescens Leaves Extract}

To identify the active fractions, the $\mathrm{H}_{2} \mathrm{O} / \mathrm{EtOH} 1 / 1$ extract of $Q$. pubescens leaves was then fractionated over silica gel (normal phase). The fractionation of the bulk extract led to the recovery of 5 distinct fractions: F1 (250 mL cyclohexane), F2 (250 mL cyclohexane/diethyl ether 1/1), F3 (250 mL diethyl ether), F4 (250 mL methanol) and F5 (250 mL methanol/water 1/1). The resulting fractions were further evaluated for their bioactivities, and their respective compositions were addressed by HPLC (High Performance Liquid Chromatography) and GC (Gas Chromatography), as well as by UPLC-HRMS (Ultra Performance Liquid Chromatography-High Resolution Mass Spectrometry, operated in the conditions presented in the following sections).

\subsection{High Performance Liquid Chromatography}

\subsubsection{HPLC Analyses}

Crude extracts and fractions diluted at $10 \mathrm{mg} / \mathrm{mL}$ in methanol (MeOH; chromatography grade) and filtrated over $0.45 \mu \mathrm{m}$ PTFE syringe filter (polytetrafluoroethylene), were analyzed using an HPLC Agilent 1200 system (Courtaboeuf, Ile-de-France, France) equipped with a DAD (Diode Array Detector) and an ELSD (Evaporative Light Scattering Detector) operating under the following conditions: injection volume: $20 \mu \mathrm{L}$, and flow rate: $1.0 \mathrm{~mL} / \mathrm{min}$. Separations were performed on a $\mathrm{C}_{18}$ column (Phenomenex, Le Pecq, Ile-de-France, France; Luna ${ }^{\circledR} 5 \mu \mathrm{m}, 150 \mathrm{~mm} \times 4.6 \mathrm{~mm}$ i.d.). The mobile phase consisted in a multistep gradient of water $(A)$, acetonitrile $(B)$ and 2-propanol $(C)$, all acidified with $0.1 \%$ acid formic: $0-5 \mathrm{~min}, 5 \% \mathrm{~B} ; 5-40 \mathrm{~min}, 5-45 \% \mathrm{~B} ; 40-50 \mathrm{~min}, 100 \% \mathrm{~B} ; 50-55 \mathrm{~min}, 100 \% \mathrm{~B} ; 55-68 \mathrm{~min}$, $100 \%$ C, 68-70 min, 100\% C. The DAD was set at 220, 254 and $330 \mathrm{~nm}$, and ELSD conditions were set as follows: nebulizer gas pressure 3.7 bars, evaporative tube temperature $40{ }^{\circ} \mathrm{C}$ and gain 4 .

\subsubsection{Semi-Preparative HPLC}

Q. pubescens extract obtained using $\mathrm{H}_{2} \mathrm{O} / \mathrm{EtOH} 1 / 1$ was then evaporated to dryness, dissolved in methanol (50 mg/mL) and semi-preparative HPLC was performed on a $\mathrm{C}_{18}$ column (Phenomenex, Le Pecq, Ile-de-France, France; Luna ${ }^{\circledR} 5 \mu \mathrm{m}, 250 \mathrm{~mm} \times 10 \mathrm{~mm}$ i.d.). Elution was performed using a multistep gradient of water (A) and acetonitrile (B), both acidified with $0.1 \%$ acid formic: $0-5$ min, 5\% B; 5-10 $\mathrm{min}, 5-100 \% \mathrm{~B}$ and 10-14 $\mathrm{min}, 100 \% \mathrm{~B}$, under the following conditions: injection volume: $100 \mu \mathrm{L}$, and flow rate: $4.0 \mathrm{~mL} / \mathrm{min}$. Multiple injections were carried out and the resulting respective sub-fractions were pooled together.

\subsection{Gas Chromatography-Mass Spectrometry (GC-MS)}

The GC-MS analyses were performed using an Agilent 6890 gas chromatograph (Palo Alto, CA, USA) equipped with an Agilent MSD5973N mass selective detector, a multifunction automatic sampler (Combi-Pal, CTC Analytics, Zwingen, Switzerland) on an HP-1 MS capillary column (100\% polydimethylpolysiloxane; $0.2 \mathrm{~mm} \times 50 \mathrm{~mm}$; film thickness, $0.33 \mu \mathrm{m})$. Samples $(1 \mu \mathrm{L})$ were injected in splitless mode (split vent: $50 \mathrm{~mL} / \mathrm{min}-30 \mathrm{~s}$ ) and the injector was set at a temperature of $250{ }^{\circ} \mathrm{C}$. The carrier gas was helium in constant flow mode at $1 \mathrm{~mL} / \mathrm{min}$. The oven temperature was programmed to rise from $60{ }^{\circ} \mathrm{C}$ to $180{ }^{\circ} \mathrm{C}$ at $2{ }^{\circ} \mathrm{C} / \mathrm{min}$, then from $180{ }^{\circ} \mathrm{C}$ to $300{ }^{\circ} \mathrm{C}$ at $6{ }^{\circ} \mathrm{C} / \mathrm{min}$ 
and kept isothermally at $300{ }^{\circ} \mathrm{C}$ for $5 \mathrm{~min}$. Acquisition was performed in scan mode (35-500 a.m.u. (atomic mass unit)/s; scan rate: 3.15 scans/s) and mass spectra were generated at $70 \mathrm{eV}$.

Compound identifications were based on comparison of mass spectra with literature, commercial libraries NIST, Wiley, Indianapolis, IN, USA) and laboratory MS libraries built up from pure substances, combined with comparison of GC linear retention index (LRI) [29,30]. Retention indices were determined with a series of linear alkanes C8-C24 used as a reference.

\subsection{Bioassays}

\subsubsection{Materials}

Untreated 96-well plates were purchased from Thermo Nunc (Villebon-sur-Yvette, Ile-de-France, France), whereas the UV-transparent ones were obtained from Costar, Sigma-Aldrich (Saint-Quentin Fallavier, Auvergne-Rhône-Alpes, France). Adhesive films (Greiner Bio-One, Courtaboeuf, Île-de-France, France) were used to seal the 96-well plates during incubation. Samples (extracts, fractions, standards and controls) were prepared at a concentration of $3.433 \mathrm{mg} / \mathrm{mL}$ in dimethyl sulfoxide (DMSO) in $1.5 \mathrm{~mL}$ Eppendorf tubes, appropriate for the use of the automated pipetting system epMotion ${ }^{\circledR} 5075$ (Eppendorf, Montesson, Île-de-France, France).

An hydroglycerinated extract of $Q$. robur heartwood commercialized for its claimed protective activities against photo-aging, free radicals and environmental factors, was tested alongside our samples to perform direct comparison between oak-based ingredients.

\subsubsection{Instrumentation}

An automated pipetting system Eppendorf epMotion ${ }^{\circledR} 5075$ was used to carry out the bioassays. A microplate reader (Spectramax Plus 384, Molecular Devices, Wokingham, Berkshire, UK) was used to measure absorbance values. Data were acquired with the SoftMaxPro software (Molecular devices, Wokingham, Berkshire, UK) and the Prism software (GraphPad Software, La Jolla, CA, USA) was used to calculate inhibition percentages. Unless otherwise stated, the results are presented as inhibition percentages (I\%) calculated as follows:

$$
\mathrm{I} \%=\left[\left(\mathrm{OD}_{\text {control }}-\mathrm{OD}_{\text {sample }}\right) / \mathrm{OD}_{\text {control }}\right] \times 100 \text { (with OD stating for optical density) }
$$

Similarly, all OD were corrected with the blank measurement corresponding to the absorbance of the sample before addition of the substrate.

\subsubsection{DPPH Radical Scavenging Assay}

The antioxidant activity of the extracts and fractions was measured based on the scavenging activity of the stable 1,1-diphenyl-2-picrylhydrazyl (DPPH) radical according to the following method widely used to examine the antioxidant activity of plant extracts [31,32]: $150 \mu \mathrm{L}$ of a solution of ethanol/acetate buffer $0.1 \mathrm{M} \mathrm{pH}=5.4(50 / 50)$ were distributed in each well, together with $7.5 \mu \mathrm{L}$ of the extracts evaluated (final concentration per well: $100 \mu \mathrm{g} / \mathrm{mL}$ ). Trolox (3607.8 $\mu \mathrm{M}$ in DMSO) and a commercial extract of Rosmarinus officinalis L. (3.433 mg/mL in DMSO) were used as positive controls; DMSO alone constitutes the negative one $\left(\mathrm{OD}_{\text {control }}\right)$. A first $\mathrm{OD}$ reading was performed at $517 \mathrm{~nm}$ (OD blank). Then, $100 \mu \mathrm{L}$ of a DPPH solution (386.25 $\mu \mathrm{M}$ in ethanol) were distributed in each well. The plate was sealed and incubated in the dark at room temperature (RT). After $30 \mathrm{~min}$, the final OD reading was performed at $517 \mathrm{~nm}$ to assess the percentage of inhibition.

\subsubsection{Tyrosinase Assays}

Tyrosinase is a copper-containing oxidase controlling the production of melanin; it is mainly involved in the hydroxylation of L-tyrosine into L-DOPA (L-3,4-dihydroxyphenylalanine. monophenolase activity) and its further oxidation to dopaquinone (diphenolase activity). Since this 
enzyme plays a key role in melanogenesis, tyrosinase inhibitors are of great concern in the development of skin whitening agents [33]. The assays were performed as follows: $150 \mu \mathrm{L}$ of a solution of mushroom tyrosinase prepared at a concentration of $171.66 \mathrm{U} / \mathrm{mL}$ in phosphate buffer $(100 \mathrm{mM} \mathrm{pH=6.8)}$ were distributed in each well (enzyme's final concentration per well: $100 \mathrm{U} / \mathrm{mL}$ (monophenolic activity assay) or $50 \mathrm{U} / \mathrm{mL}$ (diphenolic activity assay)), together with $7.5 \mu \mathrm{L}$ of the extracts evaluated (final concentration per well: $100 \mu \mathrm{g} / \mathrm{mL}$ ). Kojic acid (3.433 mM in DMSO) and a commercial extract of Arctostaphylos uva-ursi (L.) Spreng. (3.433 mg/mL in DMSO) were used as positive controls; DMSO alone constitutes the negative one ( $\left.\mathrm{OD}_{\text {control }}\right)$. The plate was filmed and incubated at RT for $20 \mathrm{~min}$. Then, $100 \mu \mathrm{L}$ of a solution of L-tyrosine (monophenolic activity assay) or L-DOPA (diphenolic activity assay) $1 \mathrm{mM}$ in phosphate buffer $\mathrm{pH}=6.8$ (substrate's final concentration per well: $0.388 \mathrm{mM}$ ) were distributed in each well. After $20 \mathrm{~min}$ of incubation, OD reading was performed at $480 \mathrm{~nm}$ to assess the percentage of inhibition.

\subsubsection{Lipoxygenase Assay}

Lipoxygenase, an iron-containing enzyme catalyzing the deoxygenation of polyunsaturated fatty acids into the corresponding hydroperoxides, is known to play a key role in inflammation [34]. The assays are performed as follows: $150 \mu \mathrm{L}$ of a solution of soybean lipoxygenase prepared at a concentration of $686.66 \mathrm{U} / \mathrm{mL}$ in phosphate buffer $(50 \mathrm{mM} \mathrm{pH}=8)$ were distributed in each well (enzyme's final concentration per well: $400 \mathrm{U} / \mathrm{mL}$ ), together with $7.5 \mu \mathrm{L}$ of the extracts evaluated (final concentration per well: $100 \mu \mathrm{g} / \mathrm{mL})$. Quercetin hydrate (1000 $\mu \mathrm{M}$ in DMSO) and a commercial extract of Arnica montana L. (3.433 mg/mL in DMSO) were used as positive controls; DMSO alone constitutes the negative one $\left(\mathrm{OD}_{\text {control }}\right)$. The plate was sealed and was incubated in the dark for $10 \mathrm{~min}$. Then, $100 \mu \mathrm{L}$ of a solution of linoleic acid prepared in phosphate buffer $\mathrm{pH}=8$ were distributed in each well. After incubation for $2 \mathrm{~min}$ in the dark, a first OD reading was performed at $235 \mathrm{~nm}$. After a further incubation of $50 \mathrm{~min}$, the final OD reading was performed at $235 \mathrm{~nm}$ to assess the percentage of inhibition.

\subsubsection{Elastase Assay}

Elastase is a serine protease that preferentially digests elastin, the highly elastic protein that works together with collagen to give skin its shape and firmness [35]. The assays were performed as follows: $150 \mu \mathrm{L}$ of a solution of porcine pancreatic elastase prepared at a concentration of $0.171 \mathrm{U} / \mathrm{mL}$ in Tris buffer $(50 \mathrm{mM} \mathrm{pH}=8)$ were distributed in each well (enzyme's final concentration per well: $0.1 \mathrm{U} / \mathrm{mL}$ ), together with $7.5 \mu \mathrm{L}$ of the extracts evaluated (final concentration per well: $100 \mu \mathrm{g} / \mathrm{mL}$ ). Quercetin hydrate (8583.33 $\mu \mathrm{M}$ in DMSO) and a commercial extract of Rubus idaeus L. (3.433 mg/mL in DMSO) were used as positive controls; DMSO alone constitutes the negative one $\left(\mathrm{OD}_{\text {control }}\right)$. The plate was filmed and incubated at RT for $20 \mathrm{~min}$. A first OD reading was performed at $410 \mathrm{~nm}$. Then, $100 \mu \mathrm{L}$ of a solution of $N$-succinyl-Ala-Ala-Ala- $p$-nitroanilide $2.06 \mathrm{mM}$ in Tris buffer (Suc-AAA-pNA's final concentration per well: $0.8 \mathrm{mM}$ ) were distributed in each well. After $40 \mathrm{~min}$ incubation, OD reading was performed at $410 \mathrm{~nm}$ to assess the percentage of inhibition.

\subsubsection{Hyaluronidase Assay}

Hyaluronidases are a family of enzymes that degrade hyaluronic acid, a high-molecular-weight glycosaminoglycan of the extracellular matrix. Presenting a unique capacity to bind and retain water molecules, this macromolecule is widely distributed in the body and notably at the periphery of collagen and elastin fibers: it therefore plays a major role in skin aging [36,37]. The assays were performed as follows: $150 \mu \mathrm{L}$ of a solution of hyaluronidase prepared at a concentration of $13.3 \mathrm{U} / \mathrm{mL}$ in hyaluronidase buffer ( $\mathrm{pH} 7$ ) were distributed in each well, together with $7.5 \mu \mathrm{L}$ of the extracts evaluated (final concentration per well: $100 \mu \mathrm{g} / \mathrm{mL})$. Tannic acid $(0.435 \mathrm{mg} / \mathrm{mL}$ in DMSO and a commercial extract of Rubus idaeus L. (3.433 mg/mL in DMSO) were used as positive controls; DMSO alone constitutes the negative one $\left(\mathrm{OD}_{\text {control }}\right)$. The plate was filmed and incubated at $37^{\circ} \mathrm{C}$ for $20 \mathrm{~min}$. A first 
OD reading was performed at $405 \mathrm{~nm}$. Then, $100 \mu \mathrm{L}$ of a solution of hyaluronic acid prepared at a concentration of $150 \mu \mathrm{g} / \mathrm{mL}$ in buffer ( $\mathrm{pH}$ 5.35) were distributed in each well. After 30 min incubation at $37^{\circ} \mathrm{C}, 50 \mu \mathrm{L}$ of $\mathrm{CTAB}$ (cetyltrimethylammonium bromide) prepared at a concentration of $40 \mathrm{mM}$ in a $\mathrm{NaOH}$ solution $(2 \%)$ were added in each well and OD reading was performed at $405 \mathrm{~nm}$ to assess the percentage of inhibition $\left(\mathrm{OD}_{\text {sample }}\right)$.

The results are presented as inhibition percentages (I\%) calculated as follows:

$$
\mathrm{I} \%=\left[\mathrm{OD}_{\text {sample }} /\left(\mathrm{OD}_{\text {blank }}-\mathrm{OD}_{\text {control }}\right)\right] \times 100
$$

\subsubsection{Collagenase Assay}

Responsible for the tensile strength of the skin, collagen constitutes therefore one of the structural units of the extracellular matrix. Collagenases are enzymes that cleave the collagen molecule within its helical region and that are more generally involved in the degradation of the extracellular matrix components, thus leading to skin wrinkling [38]. The assays were performed as follows: $150 \mu \mathrm{L}$ of a solution of collagenase prepared at a concentration of $53 \mathrm{U} / \mathrm{mL}$ in tricine buffer $(\mathrm{pH} 7.5)$ were distributed in each well, together with $7.5 \mu \mathrm{L}$ of the extracts evaluated (final concentration per well: $100 \mu \mathrm{g} / \mathrm{mL})$. Tannic acid (1.72 $\mu \mathrm{M}$ in DMSO) and a commercial extract of Glycyrrhiza glabra L. $(3.433 \mathrm{mg} / \mathrm{mL}$ in DMSO) were used as positive controls; DMSO alone constitutes the negative one $\left(\mathrm{OD}_{\text {control }}\right)$. The plate was filmed and incubated at $\mathrm{RT}$ for $15 \mathrm{~min}$. A first $\mathrm{OD}$ reading was performed at $345 \mathrm{~nm}$. Then, $100 \mu \mathrm{L}$ of a solution of FALGPA (2-furanacryloyl-L-leucylglycyl-L-prolyl-L-alanine) prepared at a concentration of $5.15 \mathrm{mM}$ in tricine buffer were distributed in each well. After $30 \mathrm{~min}$ incubation, final OD reading was performed at $345 \mathrm{~nm}$ to assess the percentage of inhibition $\left(\mathrm{OD}_{\text {sample }}\right)$.

The results are presented as inhibition percentages (I\%) calculated as follows:

$$
\mathrm{I} \%=\left[\mathrm{OD}_{\text {sample }} /\left(\mathrm{OD}_{\text {blank }}-\mathrm{OD}_{\text {control }}\right)\right] \times 100 \text {. }
$$

\subsubsection{Total Polyphenol Analysis}

The total polyphenolic content was estimated by the Folin-Ciocalteu method in 96-well plates as follows [39]: $75 \mu \mathrm{L}$ of ultrapure water were distributed in each well, together with $15 \mu \mathrm{L}$ of the extracts evaluated (final concentration per well: $100 \mu \mathrm{g} / \mathrm{mL}$ ). DMSO alone was used as negative control. Then, $25 \mu \mathrm{L}$ of a solution of Folin-Ciocalteu reagent/ultrapure water $(1 / 1)$ were added in each well. After $6 \mathrm{~min}$ incubation under agitation, $100 \mu \mathrm{L}$ of a solution of sodium carbonate $(75 \mathrm{~g} / \mathrm{L})$ were distributed in each well. The plate was then filmed and incubated at RT in the dark for $90 \mathrm{~min}$. An OD reading was performed at $765 \mathrm{~nm}$ : the amounts are expressed in milligrams of gallic acid equivalents (GAE) per gram of extract. The standard curve was prepared with gallic acid solutions (concentrations range: $200,100,50,25$ and $12.5 \mu \mathrm{g} / \mathrm{mL}$ ).

\subsubsection{Total Flavonoid Analysis}

The total flavonoid content was estimated in 96-well plates as follows: $100 \mu \mathrm{L}$ of a mixture of ultrapure water/DMSO $(1 / 1)$ were distributed in each well, together with $15 \mu \mathrm{L}$ of the extracts evaluated (final concentration per well: $100 \mu \mathrm{g} / \mathrm{mL}$ ). DMSO alone was used as negative control. Then, $10 \mu \mathrm{L}$ of a solution of aluminum trichloride $(100 \mathrm{~g} / \mathrm{L})$ were added in each well, together with $15 \mu \mathrm{L}$ of potassium acetate $(1 \mathrm{M})$ and $100 \mu \mathrm{L}$ of ultrapure water. The plate was then filmed and incubated at RT in the dark for $40 \mathrm{~min}$. An OD reading was performed at $415 \mathrm{~nm}$ : the amounts are expressed in milligrams of quercetin equivalents (QE) per gram of extract. The standard curve was prepared with quercetin hydrate solutions (concentrations range: 250, 125, 75, 25 and $5 \mu \mathrm{g} / \mathrm{mL}$ ).

\subsection{HPLC-ESI-MS Analyses}

The fraction fingerprints were obtained using an HPLC Acquity system (Waters, Guyancourt, Ile-de-France, France). Separations were performed on an Acquity UPLC Kinetex ${ }^{\circledR} C_{18}$ column 
(Phenomenex, Kinetex ${ }^{\circledR} 2.6 \mu \mathrm{m} \mathrm{C}_{18} 100 \AA, 150 \mathrm{~mm} \times 2.1 \mathrm{~mm}$ i.d.) at $25{ }^{\circ} \mathrm{C}$ with a flow rate of $0.6 \mathrm{~mL} / \mathrm{min}$. The injection volume was set at $1 \mu \mathrm{L}$. The mobile phase consisted of water (solvent $\mathrm{A}$ ) and acetonitrile (solvent B) both acidified with $0.05 \%$ formic acid (all of chromatography grade), and was used in multistep gradient mode. The gradient was operated as follows: $0-1 \mathrm{~min}, 5 \% \mathrm{~B} ; 1-9 \mathrm{~min}$, 5-40\% B; 9-15 min, 40-100\% B, 15-17 min, 100\% B; final isocratic step for $2 \mathrm{~min}$ at 5\% B. The sample manager was thermostated at $15{ }^{\circ} \mathrm{C}$. ESI (electrospray ionization) conditions operated in positive mode were set as follows: source temperature $150{ }^{\circ} \mathrm{C}$, desolvation temperature $500^{\circ} \mathrm{C}$; capillary voltage $3 \mathrm{KV}$ and cone voltage $10 \mathrm{~V}$. Nitrogen was used as cone $(10 \mathrm{~L} / \mathrm{hr})$ and desolvation gas $(1000 \mathrm{~L} / \mathrm{hr})$.

\subsection{Discoloration of the Extract}

Discoloration of the extract was performed by adsorption of the molecules responsible for the coloration on activated carbon. Discoloration of both the solid and liquid ingredients was performed with $1 \%(w / w)$ of activated carbon for $1 \mathrm{~h}$. The powdered activated carbon is then easily removed by settling and filtration.

\subsection{Development of Liquid and Solid Cosmetic Ingredients}

Solid and liquid cosmetic supports adapted to cosmetic formulation were evaluated for the development of the active ingredient.

Maltodextrin, a solid cosmetic support, was directly added to the crude extract (maltodextrin/crude extract $2 / 1 w / w$ ). The mixture is then vacuum-concentrated to dryness, and the resulting powder is homogenized using pestle and mortar.

Propylene glycol was directly used during the extraction process: about $1 \mathrm{~g}$ of the dried and crushed plant material was extracted with approximately $10 \mathrm{~g}$ of propylene glycol at RT using a magnetic stirrer $(250 \mathrm{rpm})$ for $4 \mathrm{~h}$ or $7 \mathrm{~h} 30$. The resulting extracts were then filtered over filter paper 8-12 $\mu \mathrm{m}$.

\subsection{Stability Testing}

Stability testing is performed to ensure that the ingredient developed meets the intended quality standards as well as functionality and aesthetics when stored under specific conditions. Accelerated stability testing was carried out as follows: both the ingredients on maltodextrin and in propylene glycol were stored in glass vials at $42{ }^{\circ} \mathrm{C}$, and weekly monitoring of those samples was undertaken. Evaluation of critical aesthetic properties was performed both subjectively (obvious changes in color and odor were recorded by the operator) and objectively (Section 2.10.2), and the chemical compositions of both ingredients were scrutinized by HPLC-DAD-ELSD after separation from the cosmetic supports by SPE (Solid Phase Extraction, Section 2.10.1).

\subsubsection{Solid Phase Extraction}

SPE cartridges (Phenomenex, Polymeric Reversed Phase Strata-XL, 500 mg/6 mL) were fitted into stopcocks and connected to a vacuum manifold. The sorbent was conditioned with $10 \mathrm{~mL}$ of methanol $(\mathrm{MeOH})$, and equilibrated with $10 \mathrm{~mL}$ water. With the stopcocks opened and the vacuum turned on, the SPE cartridge is then loaded with either $100 \mathrm{mg}$ of Oak2_M or with $10 \mathrm{~mL}$ of Oak3D $/ \mathrm{H}_{2} \mathrm{O}(1 / 3 \mathrm{v} / \mathrm{v})$. The vacuum pressure was set at $40 \mathrm{kPa}$. After sample addition, the column was washed first with $10 \mathrm{~mL} \mathrm{H}_{2} \mathrm{O}$, then with $10 \mathrm{~mL} \mathrm{H}_{2} \mathrm{O} / \mathrm{MeOH}(10 / 1 \mathrm{v} / v)$ and finally with $10 \mathrm{~mL}$ $\mathrm{MeOH} /$ dichloromethane $(1 / 1 v / v)$. Sample was eluted twice with $5 \mathrm{~mL} \mathrm{MeOH}$ (this stepwise elution was preferred to a single- $10 \mathrm{~mL}$ elution as it improves the final SPE yield).

\subsubsection{Color Evaluation}

Color was evaluated using a spectrophotometer Color i i $^{\mathrm{TM}} 5$ (X-Rite, Grand Rapids, MI, USA) previously calibrated with a white reference. An aliquot of each ingredient discolored or not was placed 
in glass tubes (sample thickness: $6 \mathrm{~mm}$ ). The results were expressed according to the three-dimensional color space CIE $1976 \mathrm{~L}^{*} \mathrm{a}^{*} \mathrm{~b}^{*}$ (or CIELab coordinate system, CIE-Commission Internationale de l'Éclairage), defined by the International Commission on Illumination [40]. The three coordinates (expressed as the average of triplicates measurements) denote respectively the lightness of the color $\left(\mathrm{L}^{*}\right)$, its red-versus-green attribute $\left(\mathrm{a}^{*}\right)$ and its yellow-versus-blue attribute $\left(\mathrm{b}^{*}\right)$, and $\Delta \mathrm{E}_{\mathrm{ab}}^{*}$ represents the color difference between two samples ( $\Delta \mathrm{E}_{\mathrm{ab}}^{*}$ will have no unit). This color difference is calculated as the Euclidian distance between the points representing those samples in the space, as follows:

$$
\Delta \mathrm{E}_{\mathrm{ab}}^{*}=\left[\left(\Delta \mathrm{L}^{*}\right)^{2}+\left(\Delta \mathrm{a}^{*}\right)^{2}+\left(\Delta \mathrm{b}^{*}\right)^{2}\right]^{1 / 2} .
$$

$\mathrm{A} \Delta \mathrm{E}_{\mathrm{ab}}^{*}$ between 1.00 to 2.50 represents the points at which an average individual starts to visually notice a color difference; if the $\Delta \mathrm{E}^{*}$ ab is less than 1.00 , the color difference is barely perceivable by an average human observer [41,42].

\section{Results}

As already stated, a series of Mediterranean plants were initially selected over more than 500 for the present study, based on their accessibility and their originality regarding the anti-aging activity. From this survey, it appears that crude extract of Q. pubescens leaves displays the best unprecedented anti-aging activities. Added to this, the easiness of the raw material supply in the region, and the attractive marketing potential of the resulting cosmetic active (one can play about the nobility of this truffle oak) induced its selection for further investigations.

\subsection{Crude Extract Oak1}

First, the extraction of leaves of Q. pubescens was performed with $\mathrm{H}_{2} \mathrm{O} / \mathrm{EtOH} 1 / 1$ to cover the larger polarity range possible, hence to recover a maximum of metabolites. Leaves of $Q$. pubescens collected in two locations were extracted in the same conditions and the effect of the origin of the raw material on the chemical composition of the resulting extract was investigated. The various origin of plant material induced slightly different extraction yields (ranging from $10 \%$ to $16 \%$ ); however, no major difference was evidenced in the phytochemical profiles of oak extracts obtained from leaves collected in different locations (data not shown). For convenience, the Q. pubescens extract obtained using $\mathrm{H}_{2} \mathrm{O} / \mathrm{EtOH} 1 / 1$ will further be referred to as Oak1 in the present article.

The HPLC fingerprinting of this extract revealed the presence of a large group of polyphenols eluting between 14 and 56 min (Figure 1).

\subsubsection{In Vitro Bioassays}

The bioactivities of Oak1 were assessed using in vitro bioassays, and were compared to the bioactivities of commercial cosmetic ingredients used for the respective activities tested (positive control) and to the bioactivities of a commercial oak ingredient. As presented in Figure 2, Oak1 displays real promising antioxidant and anti-hyaluronidase activities, as well as some interesting anti-inflammatory activity, compared to commercial ingredients.

\subsubsection{Fractionation Scheme 1}

To characterize the active compounds responsible for the bioactivities evidenced, Oak1 extract was then fractionated over silica gel (Table 1). The fractionation of $3.5 \mathrm{~g}$ of Oak1 led to the recovery of five distinct fractions: F1 (cyclohexane), F2 (cyclohexane/diethyl ether 1/1), F3 (diethyl ether), F4 (methanol) and F5 (methanol/water 1/1). The resulting fractions Oak1_F2 to Oak1_F5 were further evaluated for their bioactivities; no further investigation was undertaken for Oak1_F1 as even if this fraction would be interesting in terms of bioactivity, it would not be commercially viable to develop any resulting cosmetic ingredient due to it poor extraction yield. 


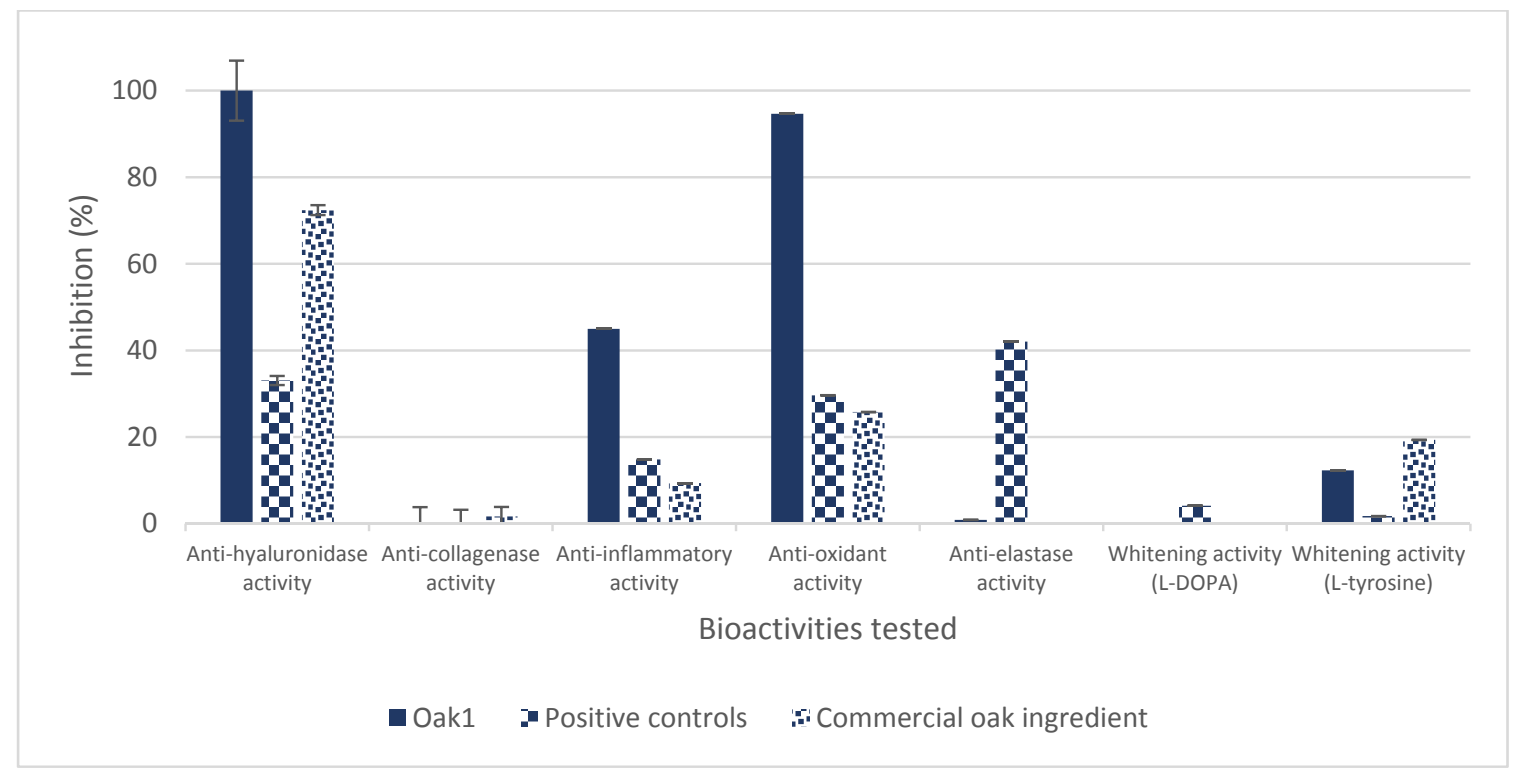

Figure 2. Bioactivities of Oak1, the $Q$. pubescens extract obtained using $\mathrm{H}_{2} \mathrm{O} / \mathrm{EtOH} 1 / 1$, compared to the bioactivities of commercial cosmetic ingredients used for the respective activities tested (positive controls) and to the bioactivities of a commercial oak ingredient.

Table 1. Extraction parameters (white cells) and bioactivities (grey cells) of the fractions F1-F5 resulting from the fractionation of the Oak1 extract.

\begin{tabular}{|c|c|c|c|c|c|c|}
\hline $\begin{array}{c}\text { Extraction } \\
\text { Parameters/Bioactivities }\end{array}$ & Oak1_F1 & Oak1_F2 & Oak1_F3 & Oak1_F4 & Oak1_F5 & $\begin{array}{l}\text { Positive } \\
\text { Control }\end{array}$ \\
\hline Extraction ( $250 \mathrm{~mL}$ solvent) & cyclohexane & $\begin{array}{c}\text { cyclohexane } \\
\text { /diethyl ether } 1 / 1\end{array}$ & diethyl ether & methanol & $\begin{array}{l}\text { methanol/ } \\
\text { water } 1 / 1\end{array}$ & \\
\hline Fractions' mass & $0.60 \mathrm{mg}$ & $34.00 \mathrm{mg}$ & $150.50 \mathrm{mg}$ & $304.00 \mathrm{mg}$ & $2.34 \mathrm{~g}$ & \\
\hline Yield & $0.02 \%$ & $0.96 \%$ & $4.24 \%$ & $28.53 \%$ & $65.98 \%$ & \\
\hline Whitening L-DOPA & n.d. & - & - & - & - & ++++ \\
\hline activity L-Tyrosine & n.d. & - & - & - & - & ++++ \\
\hline Anti-inflammatory activity & n.d. & - & - & - & - & +++ \\
\hline Anti-collagenase activity & n.d. & - & - & - & - & - \\
\hline Anti-elastase activity & n.d. & + & +++ & ++ & + & ++++ \\
\hline Anti-oxidant activity & n.d. & - & - & ++++ & ++++ & - \\
\hline Anti-hyaluronidase activity & n.d. & - & - & ++++ & ++++ & ++ \\
\hline
\end{tabular}

n.d.: not determined; (-): inhibition < 30\%; (+): 30\% < inhibition < 50\%; (++): 50\% < inhibition < 70\%; $(+++)$ : $70 \%<$ inhibition <90\%; $(++++)$ : inhibition $>90 \%$.

Fraction solutions were concentrated at $3.433 \mathrm{mg} / \mathrm{mL}$ in DMSO and their activities were assessed the same way as the one of crude extract. Results of these bioassays are presented in Table 1. No remarkable bioactivity was observed for Oak1_F2, and no further investigation was initiated. Some interesting anti-elastase activity was reported for Oak1_F3. Both fractions Oak1_F4 and Oak1_F5 were identified as potent anti-oxidants and significant hyaluronidase inhibitors, similarly to the crude extract Oak1. These fractions also display some anti-elastase activity.

The crude extract Oak1, as well as fractions Oak1_F3, Oak1_F4 and Oak1_F5, were further analyzed by GC-MS. The compounds identified are listed in Table 2. Apart from dihydroactinidiolide, 6,10,14-trimethyl-2-pentadecanone and dihydro-2.3-benzofuran, which were not available at the laboratory, all of these compounds were assayed for their bioactivities. Only nonanal displayed some interesting anti-elastase activity that can be linked to the anti-elastase activity evidenced for Oak1_F3. 
Table 2. Major compounds identified by GC-MS in crude extract Oak1, as well as in fractions Oak1_F3, Oak1_F4 and Oak1_F5.

\begin{tabular}{|c|c|c|c|}
\hline Extract/Fraction & Constituant & RI ${ }^{a, b}$ HP-1/RI Lit & References \\
\hline Oak1 & 6,10,14-trimethyl-2-pentadecanone & $1827 / 1830$ & identified in Q. robur leaves essential oil [43] \\
\hline \multirow{7}{*}{ Oak1_F3 } & nonanal & $1081 / 1082$ & $\begin{array}{l}\text { identified in Q. pyrenaica and Q. petraea wood } \\
\text { extracts [44], as well as in Q. agrifolia and } \\
\text { Q. robur leaves essential oils }[43,45]\end{array}$ \\
\hline & dihydroactinidiolide & $1481 / 1475$ & identified in Q. dentata leaves essential oil [46] \\
\hline & dodecanoic acid & $1543 / 1547$ & $\begin{array}{l}\text { identified in Q. robur and Q. petraea wood } \\
\text { extracts [47] }\end{array}$ \\
\hline & tetradecanoic acid & $1743 / 1750$ & $\begin{array}{l}\text { identified in Q. robur and Q. petraea wood } \\
\text { extracts [47], as well as in Q. robur leaves } \\
\text { essential oil [43] }\end{array}$ \\
\hline & methyl palmitate & 1903/1909 & - \\
\hline & hexadecanoic acid & $1945 / 1940$ & $\begin{array}{l}\text { identified in Q. robur, Q. petraea and Q. alba } \\
\text { wood extracts }[47,48] \text {, as well as in Q. robur } \\
\text { leaves essential oil [43] }\end{array}$ \\
\hline & linoleic acid & $2105 / 2109$ & $\begin{array}{l}\text { identified in Q. robur, Q. petraea and Q. alba } \\
\text { wood extracts }[47,48]\end{array}$ \\
\hline \multirow{2}{*}{ Oak1_F4 } & dihydro-2.3-benzofuran & $1197 / 1188$ & \\
\hline & 6,10,14-trimethyl-2-pentadecanone & $1827 / 1830$ & identified in Q. robur leaves essential oil [43] \\
\hline \multirow{2}{*}{ Oak1_F5 } & furfural & $805 / 805$ & identified in Q. suber wood [49] \\
\hline & furfuryl acohol & $838 / 835$ & - \\
\hline
\end{tabular}

${ }^{\mathrm{a}}$ Compounds are listed in order of their elution time from an HP- 1 column. ${ }^{\mathrm{b}} \mathrm{RI}=$ retention indices are determined on HP-1 column using the homologous series of $n$-alkanes (C8-C24).

The total phenolic acid and flavonoid contents of Oak1_F3, Oak1_F4 and Oak1_F5 were then determined. The results respectively presented in Figures 3 and 4 show correlations between those contents and the activities previously evidenced for the respective fractions.

The crude extract Oak1, as well as fractions Oak1_F4 and Oak1_F5, all presenting a strong anti-oxidant potency, appear to be quite rich in polyphenolic compounds; such correlation between chemical composition and antioxidant activity was already reported in the literature [50-52]. HPLC-ESI-MS analysis of fraction Oak1_F4 reveals that it is mainly constituted of catechin, a flavanol already known to act as a powerful antioxidant [53].

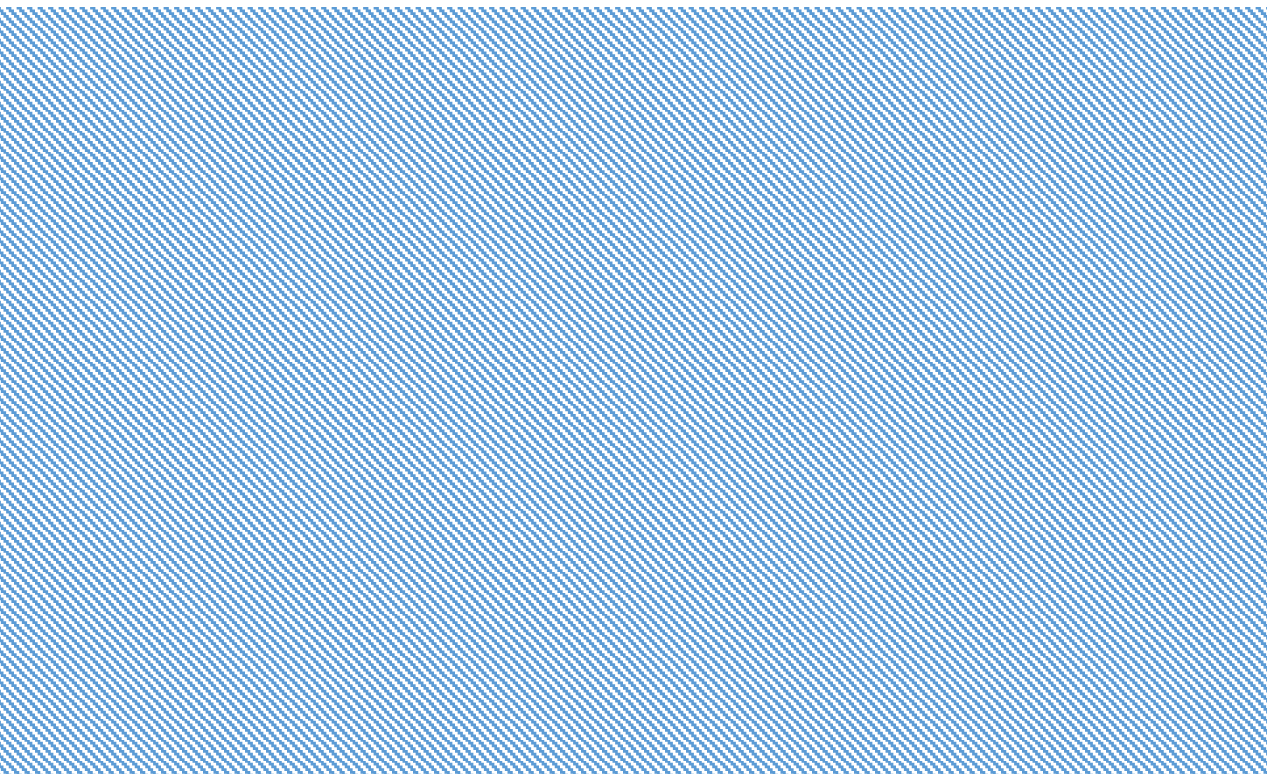

Figure 3. Total phenolic content of the $\mathrm{H}_{2} \mathrm{O} / \mathrm{EtOH}(1 / 1)$ extract Oak1 and the three fractions Oak1_F3, Oak1_F4 and Oak1_F5 (GAE stands for gallic acid equivalent). 


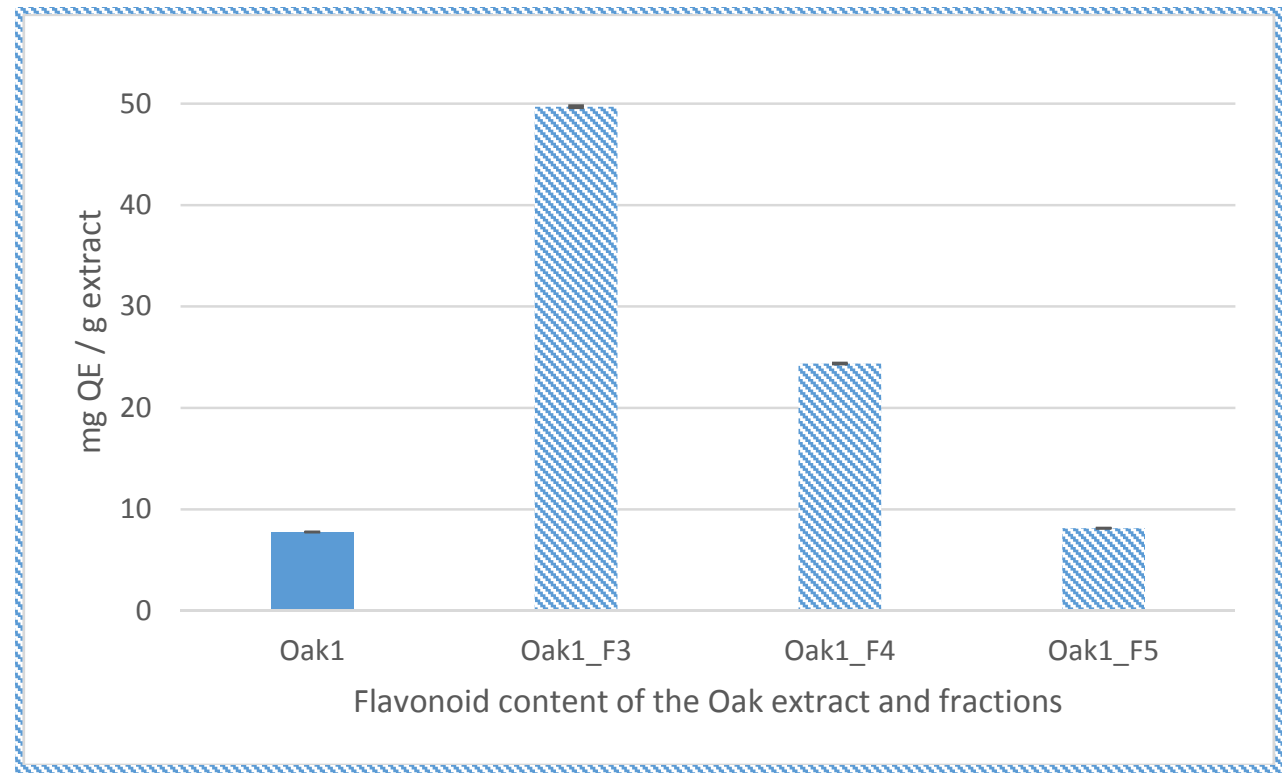

Figure 4. Total flavonoid content of the $\mathrm{H}_{2} \mathrm{O} / \mathrm{EtOH}(1 / 1)$ extract Oak1 and the three fractions Oak1_F3, Oak1_F4 and Oak1_F5 (QE stands for quercetin equivalent).

Positive relationships were also observed between anti-hyaluronidase activity and phenolic content in the cases of fractions Oak1_F4 and Oak1_F5, as well as between anti-elastase activity and flavonoid content in the cases of fraction Oak1_F3 and to a lesser extent, of fraction Oak1_F4, as previously stated in the literature [52,54].

\subsubsection{Fractionation Scheme 2}

From the previous results (Section 3.1.2), it appeared that the molecules responsible for the bioactivities tested are concentrated in the most polar fractions resulting from Oak1 fractionation scheme 1, i.e., the fractions obtained with diethyl ether, $\mathrm{MeOH}$ and $\mathrm{MeOH} / \mathrm{H}_{2} \mathrm{O} 1 / 1$. To gain information about these metabolites, the Oak1 extract concentrated at $50 \mathrm{mg} / \mathrm{mL}$ in $\mathrm{MeOH}$ was roughly fractionated by semi-preparative HPLC as described in the Materials and Methods section to separate polar (Oak1_PF eluting between 0-7 min; yield: 62\%) from less polar compounds (Oak1_LPF eluting between 7-14 min; yield: 38\%; Figure 5). Several injections were realized and successive polar/less polar fractions were respectively pulled together to recover enough material to assess their bioactivities the same way as the one of Oak1.

No remarkable bioactivity was observed for Oak1_PF obtained with water added up with 5\% of acetonitrile: this fraction is constituted of more polar compounds that the ones extracted in the previous fractions Oak1_F3 to Oak1_F5. The less polar compounds extracted in Oak1_LPF appear to be mainly responsible for the activities reported for Oak1: a large amount of polyphenols eluting between 10 and 50 min were notably identified based on their UV spectra and by comparison with standards available at the laboratory (Figure 6). In fact, Oak1_LPF present similar anti-inflammatory and anti-hyaluronidase activities, and appear to be a slightly less potent anti-oxidant, compared to Oak1 (Figure 7). Some interesting anti-elastase activity was reported for Oak1_LPF, revealing a potential antagonistic effect between both fractions, the polar one impeding the activity of the less polar one against this enzyme.

From the two fractionation strategies adopted, it appears that the compounds responsible for the bioactivities of Oak1 are of intermediate polarity. The subsequent process adopted to further develop oak-based cosmetic ingredients will be adapted to preferentially extract those compounds and hence potentialize their bioactivities. 


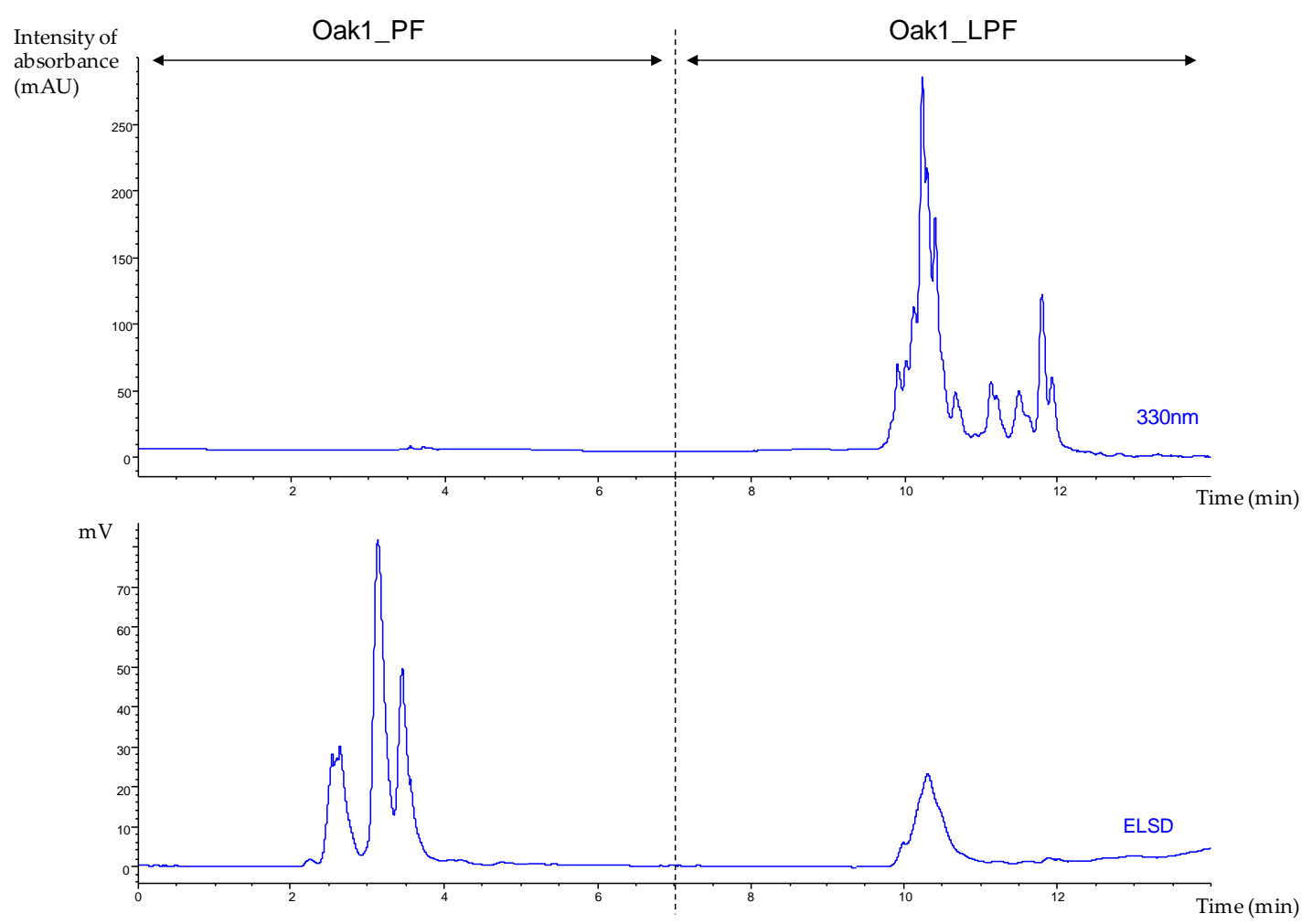

Figure 5. Semi-preparative HPLC chromatograms obtained on a Luna ${ }^{\circledR} \mathrm{C}_{18}$ column $(250 \mathrm{~mm} \times 10 \mathrm{~mm}$; $5 \mu \mathrm{m})$ at $330 \mathrm{~nm}$ and with ELSD, presenting the two fractions resulting from Oak1 fractionation.

Sugars, amino acids, peptides, etc

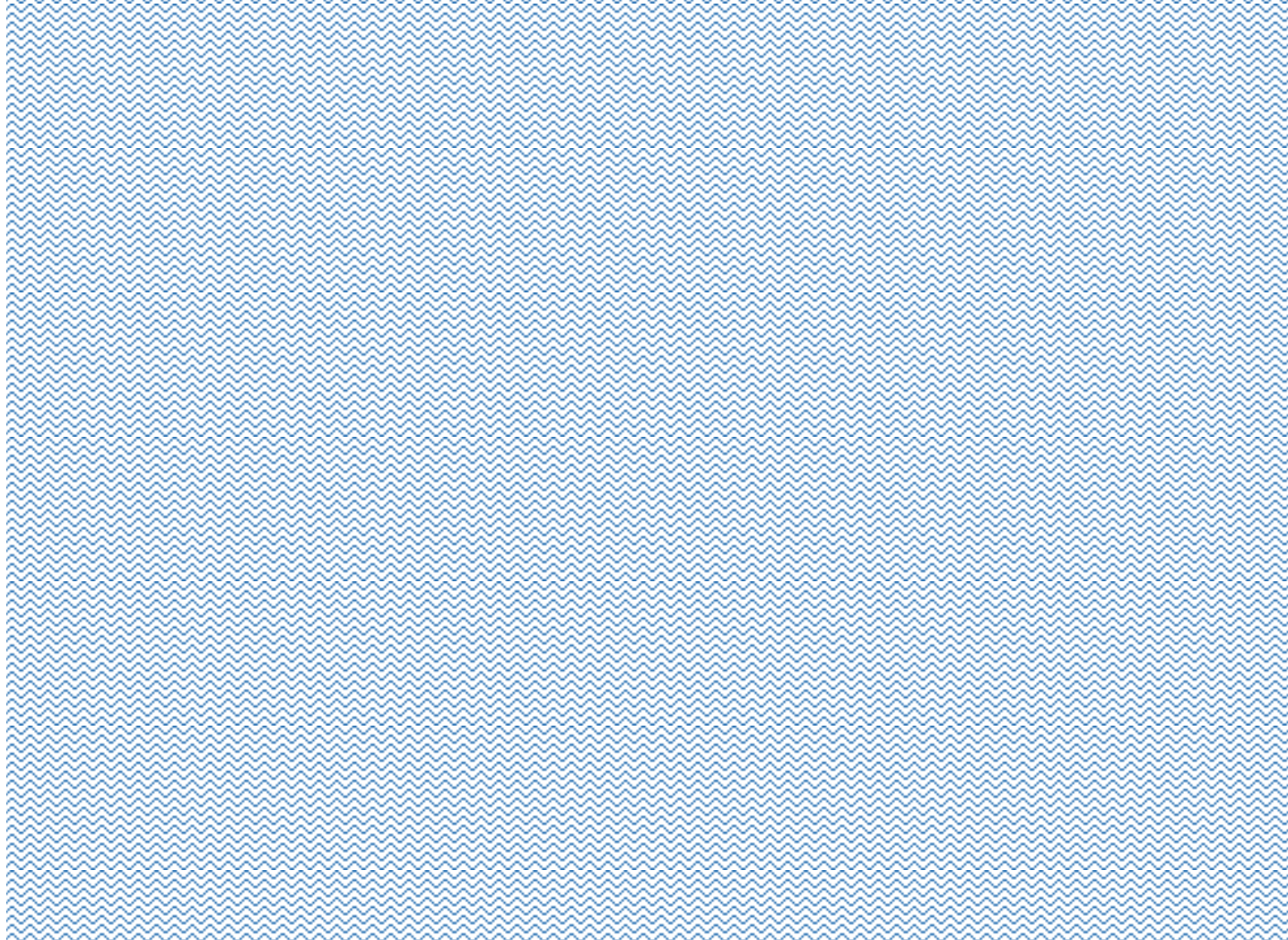

Figure 6. HPLC chromatograms obtained on a Luna ${ }^{\circledR} \mathrm{C}_{18}$ column $(150 \mathrm{~mm} \times 4.6 \mathrm{~mm} ; 5 \mu \mathrm{m})$ at $330 \mathrm{~nm}$ and with ELSD, presenting the major families of compounds identified in Oak1_LPF fraction. 


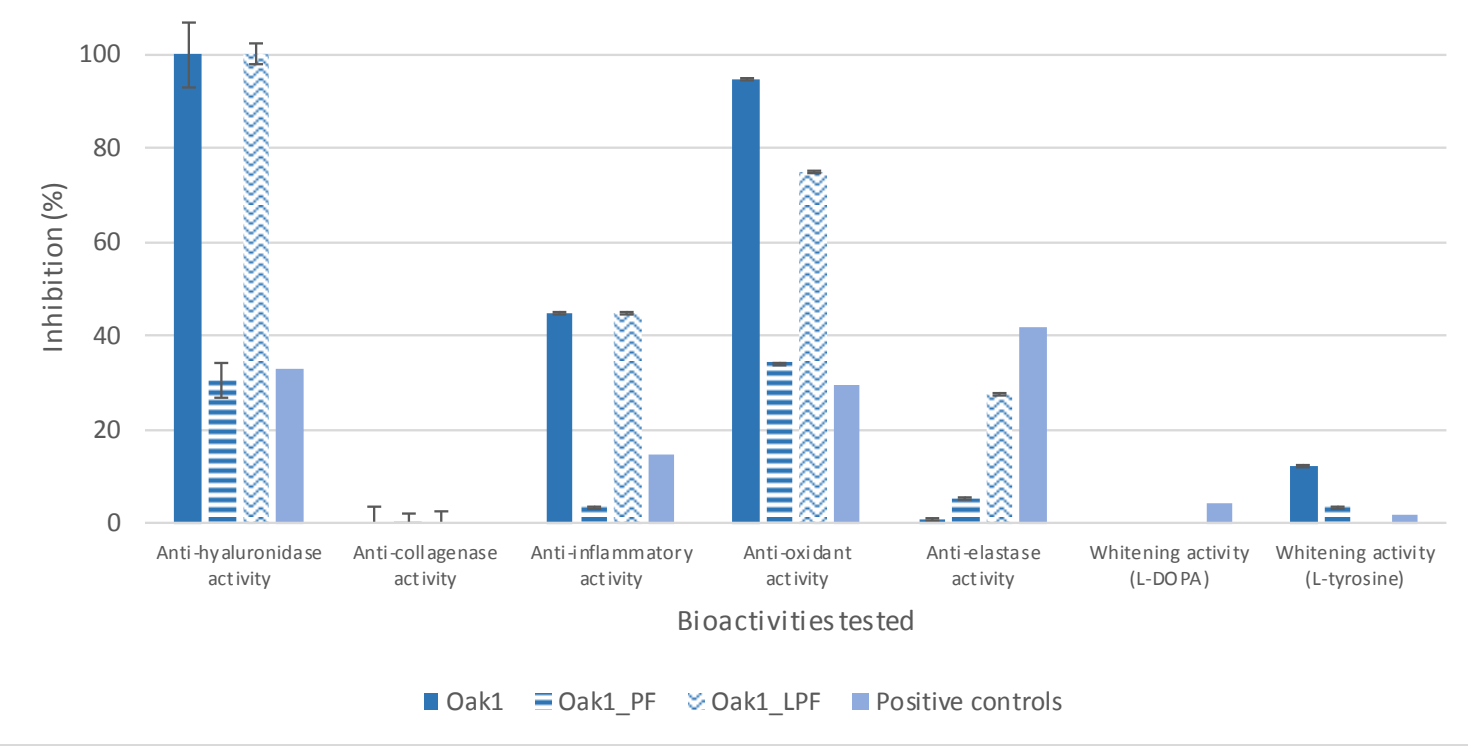

Figure 7. Bioactivities of Oak1, the $Q$. pubescens extract obtained using $\mathrm{H}_{2} \mathrm{O} / \mathrm{EtOH} 1 / 1$, compared to the ones of Oak1_PF, Oak1_LPF and of commercial cosmetic ingredients used for the respective activities tested (positive controls).

\subsection{Development of Cosmetic Ingredients}

Once the active fraction identified, the corresponding natural cosmetic ingredient can be developed. The necessary requirements for such a development are quite numerous, as evidenced in Figure 8: natural extracts or fractions that display interesting bioactivities are usually not directly incorporable into a formulation as they may display undesirable qualities (color, odor, viscosity, etc.). The addition of an appropriate cosmetic support, either liquid or solid, can be necessary to facilitate the incorporation of natural actives into a cosmetic formulation.

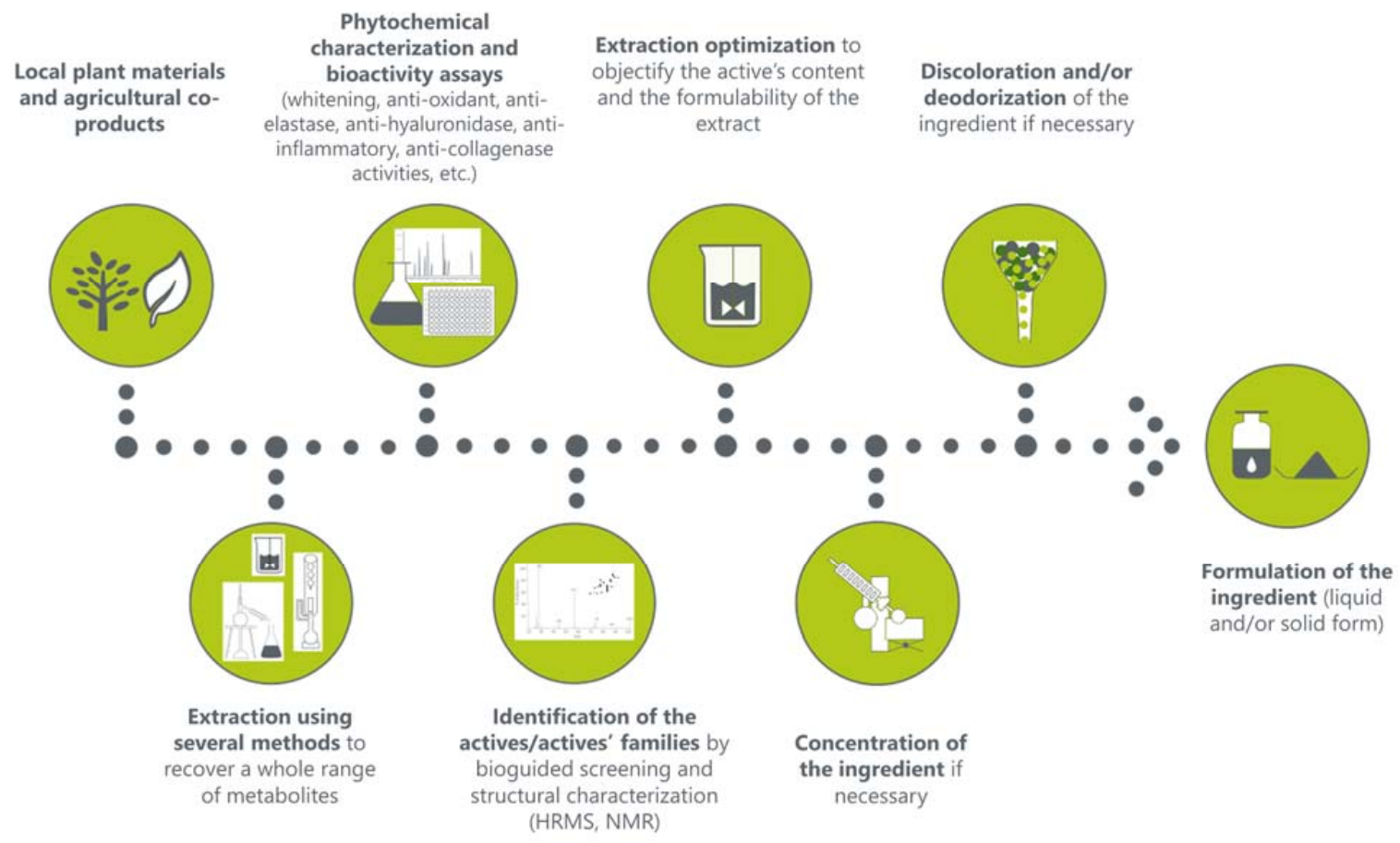

Figure 8. Strategy adopted to develop a natural cosmetic ingredient, from plant sourcing to formulation. 


\subsubsection{Solid Cosmetic Ingredient}

As already stated in Section 3.1, the compounds responsible for the bioactivities of Oak1 are of intermediate polarity, so $\mathrm{H}_{2} \mathrm{O} / \mathrm{EtOH} 1 / 1$ is not the most convenient solvent system for the further development of an oak-based cosmetic ingredient. Added to this observation, one can argue that the elimination of water through concentration by vacuum evaporation is highly energy-consuming, and such a solvent system is hence not the most appropriate one for the ingredients' industrial production. To objectivate the active metabolites' content of the future ingredient and to facilitate the industrial scale-up of its fabrication process, $\mathrm{H}_{2} \mathrm{O} / \mathrm{EtOH} 1 / 1$ was replaced by pure EtOH: for convenience, the $Q$. pubescens extract obtained by 2 h-maceration of $Q$. pubescens leaves in ethanol will further be referred to as Oak2 in the present article (extraction yield range: 3-5\%). The bioactivities of Oak2 were assessed using in vitro bioassays. As presented in Figure 9, apart from the promising antioxidant and anti-hyaluronidase activities already evidenced in the $\mathrm{H}_{2} \mathrm{O} / \mathrm{EtOH} 1 / 1$ extract Oak1, Oak2 also displays some anti-inflammatory activity and especially some very interesting anti-elastase activity.

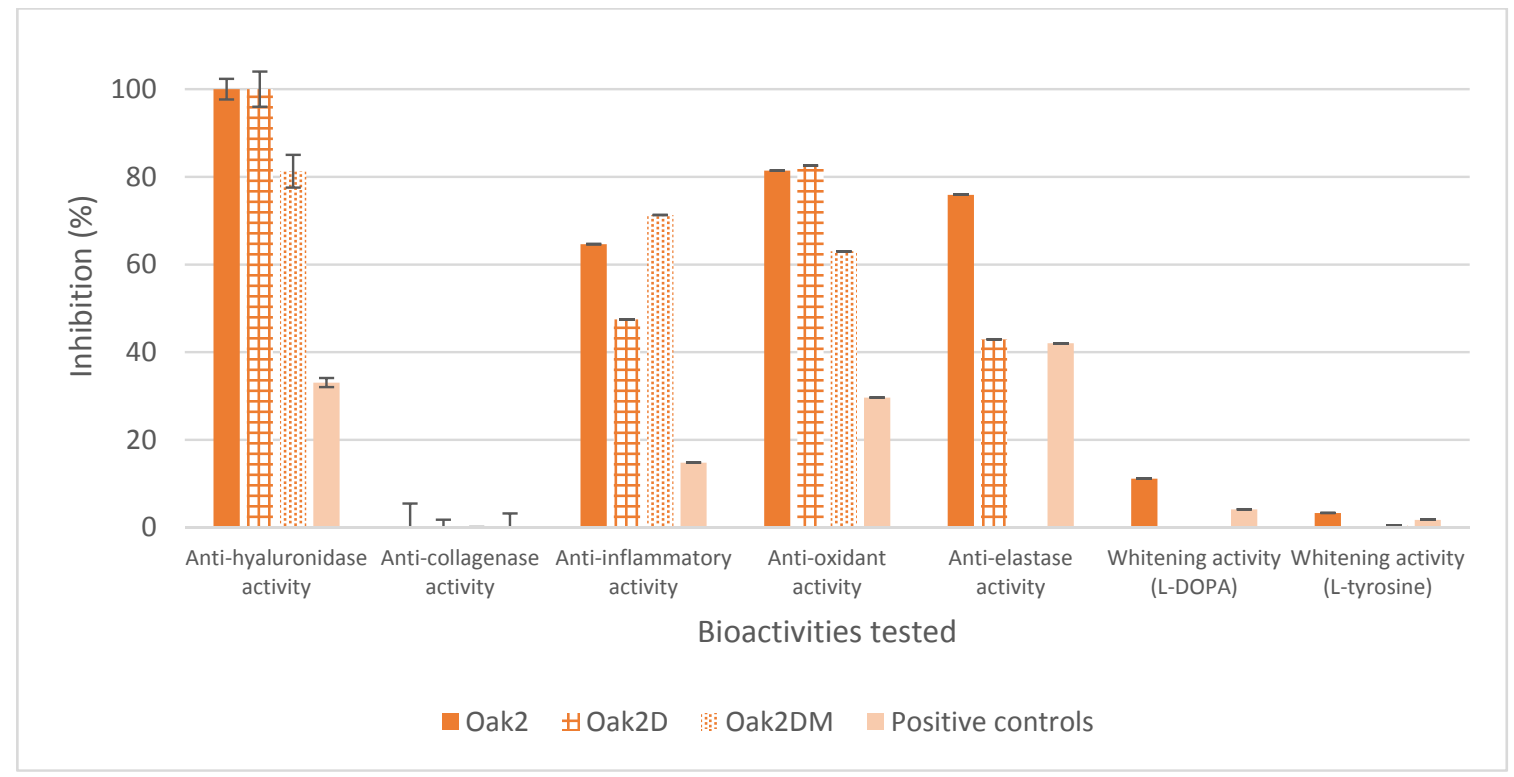

Figure 9. Bioactivities of Oak2, the $Q$. pubescens extract obtained using pure ethanol, compared to the bioactivities of the discolored extract Oak2D, of the discolored extract deposited on maltodextrin Oak2DM and of commercial cosmetic ingredients used for the respective activities tested (positive controls).

The organic solvents used to extract active molecules from a plant also extract the molecules responsible for the plant's color, which are generally unacceptable in skin care products [55] and need therefore to be submitted to further processing, including notably a discoloration procedure. Discoloration can be performed by adsorption of the undesirable molecule on activated carbon: the powdered activated carbon can easily be added to the liquid extract, and then removed by settling and filtration. Several discoloration conditions were tested using varying discoloration durations and various extract/activated carbon ratios. The best results were obtained when Oak2's discoloration was performed with $1 \%(w / w)$ of activated carbon for $1 \mathrm{~h}$. The resulting appropriately discolored extract Oak2D (Table 3: $\Delta \mathrm{E}_{\mathrm{ab}}^{*}>2.5$, indicating a color difference easily perceivable to the human eye) was recovered after elimination of the activated carbon (recover yield range: $55-60 \%$ ) and its bioactivities were assessed using in vitro bioassays. Regarding the results presented in Figure 9, one can conclude that the discoloration does not affect the antioxidant and anti-hyaluronidase activities of the extract, but some losses of anti-inflammatory and anti-elastase activities are made evident. 
Table 3. Color variations (with SD, standard deviation) observed for both solid and liquid cosmetic ingredients after activated carbon discoloration.

\begin{tabular}{|c|c|c|c|c|c|}
\hline \multirow{2}{*}{\multicolumn{2}{|c|}{ Oak Ingredients }} & \multicolumn{4}{|c|}{ Color Characteristics } \\
\hline & & $\mathrm{L}^{*}$ (Lightness) $\pm \mathrm{SD}$ & $a *$ (Redness) \pm SD & b *(Yellowness) \pm SD & $\Delta \mathrm{E}^{*}{ }_{\mathrm{ab}} \pm \mathrm{SD}$ \\
\hline $\begin{array}{c}\text { Solid } \\
\text { ingredient }\end{array}$ & $\begin{array}{c}\text { Oak2 } \\
\text { Oak2D }\end{array}$ & $\begin{array}{l}-32.16 \pm 0.03 \\
-26.73 \pm 0.96\end{array}$ & $\begin{array}{l}26.71 \pm 0.03 \\
28.42 \pm 0.09\end{array}$ & $\begin{array}{c}-12.76 \pm 0.04 \\
-6.89 \pm 1.56\end{array}$ & $8.18 \pm 1.79$ \\
\hline $\begin{array}{c}\text { Liquid } \\
\text { ingredient }\end{array}$ & $\begin{array}{c}\text { Oak3 } \\
\text { Oak3D } \\
\text { Oak4 } \\
\text { Oak4D }\end{array}$ & $\begin{array}{l}-29.92 \pm 0.19 \\
-30.42 \pm 0.13 \\
-29.92 \pm 0.19 \\
-30.99 \pm 0.05\end{array}$ & $\begin{array}{l}27.06 \pm 0.03 \\
27.01 \pm 0.03 \\
27.06 \pm 0.03 \\
27.17 \pm 0.04\end{array}$ & $\begin{array}{l}-13.84 \pm 0.04 \\
-13.55 \pm 0.05 \\
-13.84 \pm 0.04 \\
-13.27 \pm 0.06\end{array}$ & $\begin{array}{l}0.58 \pm 0.06 \\
1.22 \pm 0.14\end{array}$ \\
\hline
\end{tabular}

Maltodextrin, a solid agent used in cosmetics to bind other compounds and stabilize formulas, was then added to the extract Oak2D (maltodextrin/crude extract 2/1 w/w). The mixture is then vacuum-concentrated to dryness, and the resulting powder (Oak2DM) is homogenized using pestle and mortar. The bioactivities of Oak2DM, as well as of maltodextrin alone (no activity reported; data not shown), were assessed using in vitro bioassays as already enunciated (at the same concentration as the extracts and fractions). Regarding the results presented in Figure 9, one can conclude that the addition of maltodextrin does not affect significantly the anti-hyaluronidase, the anti-oxidant and the anti-inflammatory activities of the extract, but a dramatic loss of anti-elastase activity compared to the crude extract Oak2 is made evident.

The solid ingredient Oak2DM developed here appears to be an efficient active to be incorporated in cosmetic anti-age formula. However, some optimization could still be done in the development of this solid oak ingredient. Some further discoloration trials should be undertaken to reach the same discoloration level or even a better one, without such a mass loss. One can also imagine that adjustments in the ratio of maltodextrin added to the discolored extract may potentially lead to less anti-elastase bioactivity's loss.

\subsubsection{Liquid Cosmetic Ingredient}

Liquid ingredients are preferred to formulate some cosmetics. Propylene glycol is one of the most widely used cosmetic supports: it serves as a humectant, a viscosity decreasing agent and as a solvent, so it is employed in many personal care formulations including facial cleansers, moisturizers, etc. Owing to its polarity, it was tested to directly extract the active metabolites of Q. pubescens leaves: leaves macerate in propylene glycol (dried plant/propylene glycol $1 / 10 w / w)$ for $4 \mathrm{~h}$ at room temperature. For convenience, the subsequent $Q$. pubescens extract will further be referred to as Oak3 in the present article.

Subsequent discoloration of Oak3 was undertaken. Several attempts were realized using varying Oak3/activated carbon ratios and discoloration times. From these tests, it appeared that the most suitable discoloration parameters consist in the addition of $1 \%(w / w)$ of activated carbon for $1 \mathrm{~h}$ : the discolored extract further referred to as Oak3D, was recovered after elimination of the activated carbon. From the color measurements presented in Table 2, it appears that the $\Delta \mathrm{E}^{*}$ ab is less than 1.00 , indicating a color difference barely perceivable by an average human observer. Thus, one can conclude that additional discoloration attempts must be undertaken to obtain an appropriately discolored liquid extract.

The bioactivities of Oak3 and Oak3D, as well as the ones of propylene glycol alone (no activity reported; data not shown) were assessed using in vitro bioassays (Figure 10): no interesting bioactivities were evidenced.

Another attempt was then performed using a greater maceration time: oak leaves macerate in propylene glycol (dried plant/propylene glycol $1 / 10 w / w$ ) for $7 \mathrm{~h} 30$ at room temperature. The subsequent $Q$. pubescens extract, referred to as Oak4 displays some promising anti-hyaluronidase, anti-inflammatory and anti-oxidant activities (Figure 10). However, further discoloration of Oak4 
using $0.1 \%(w / w)$ of activated carbon for $2 \mathrm{~h} 30$ (efficient discoloration: $\Delta \mathrm{E}_{\mathrm{ab}}^{*}>1$; Table 2 ) dramatically affects all the bioactivities evidenced before the use of activated carbon (Oak4D displays no activity at all; data not shown).

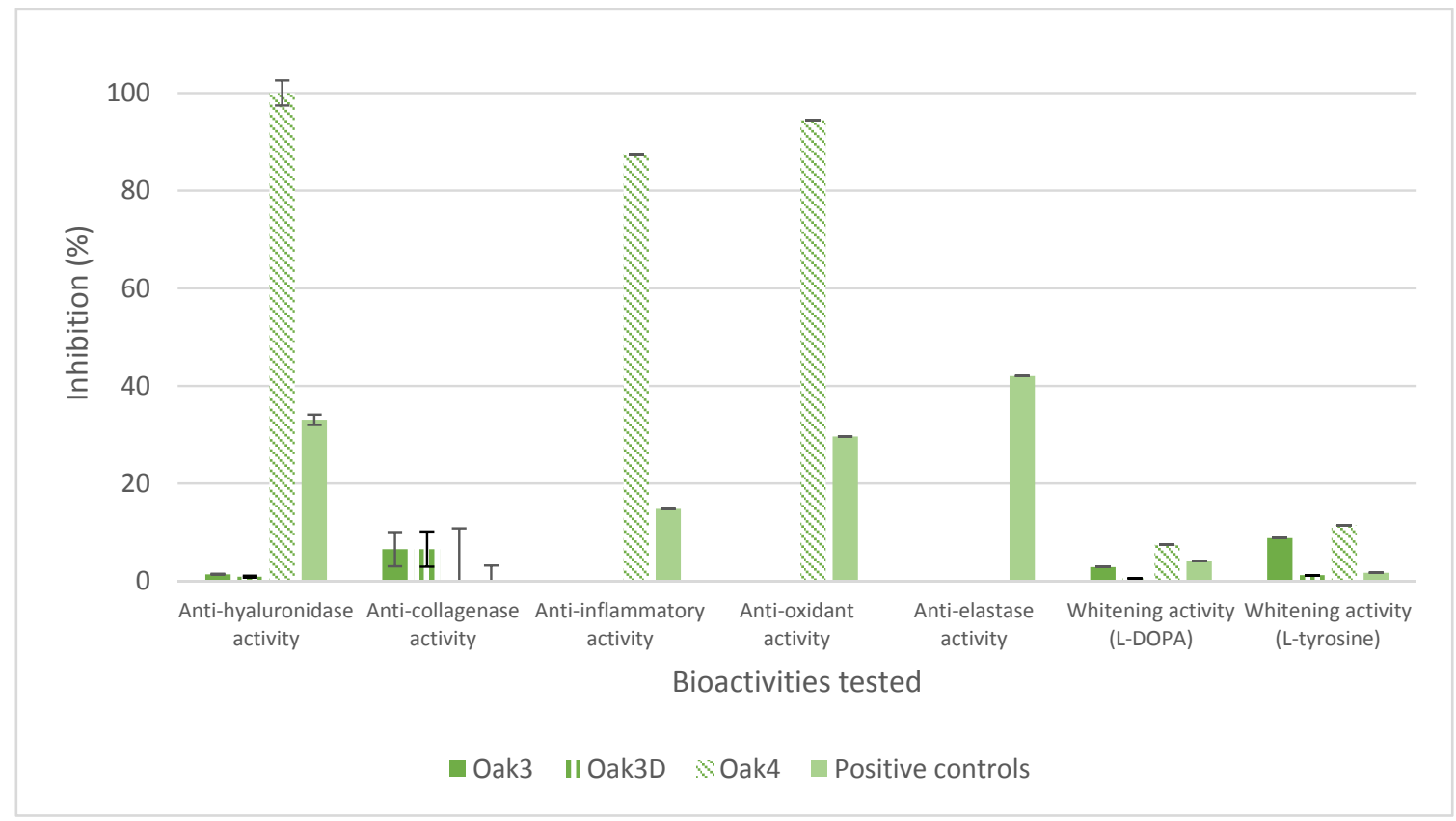

Figure 10. Bioactivities of Oak3 and Oak 4, the Q. pubescens extracts obtained using propylene glycol, compared to the bioactivities of the discolored extract Oak3D and of commercial cosmetic ingredients used for the respective activities tested (positive controls).

From these results, it appears quite clearly that maceration time highly influences the bioactivities of the subsequent extract. Nevertheless, some further discoloration trials should be undertaken to reach appropriate discoloration, while preserving the extremely interesting anti-aging activity of Oak4. Finally, greener glycols are also currently tested to develop an even more natural cosmetic ingredient.

\subsubsection{Stability Tests}

Accelerated stability testing that was carried out were performed in glass vials at $42{ }^{\circ} \mathrm{C}$ to ensure that the ingredients developed meet the intended quality standards as well as functionality and aesthetics when stored under specific conditions. As no regulation exists regarding how to perform this kind of tests, the specific testing conditions are defined by the manufacturer. Typically, decisions are made whether the product is stable or not after eight weeks of testing, and a consensus exists that states that if a product is stable after eight weeks at $45^{\circ} \mathrm{C}$, it corresponds to stability after a one-year storage at room temperature.

In the present case, periodic monitoring of those samples is currently undertaken: visual/olfactory evaluation of critical aesthetic properties such as color, fragrance, texture is performed, and the chemical compositions of both ingredients are scrutinized weekly. The evolution of the molecular composition of these finished ingredients, and particularly of their phenolic contents, is followed by HPLC in the same experimental conditions (Section 2.4.1). The tests are not over, but so far, i.e., one month after the beginning of the stability test, no modification of the composition of the ingredient was noticed, but further investigations should confirm these observations.

Furthermore, it would be necessary to push these stability tests forwards once the definite formulation has been determined: additional tests should be performed in an aging chamber where the effect of temperature/lighting variations mimicking the ones a finished product is submitted to, from formulation to consumer's use, could be monitored. 


\subsection{Formulation}

An example of an anti-aging formula integrating the natural cosmetic ingredient, developed based on truffle oak leaves, is given in Table 4. The ingredient is titrated enough to be efficient even when incorporated in a low amount in a formula: depending on the activity wished for, the oak active, either solid or liquid, is incorporated in the formula in quantities ranging from $0.10 \%$ to $1.00 \%$, and the quantity of the aqueous phase is consequently adjusted to respect the formula's proportions.

Table 4. Example of an anti-age formulation using the Q. pubescens ingredient.

\begin{tabular}{cc}
\hline INCI ${ }^{\text {a }}$ Name & Quantity (\%) \\
\hline Aqua & q.s. ${ }^{\mathrm{b}} 100$ \\
Glycerin & 1.00 \\
Stearic acid (and) Palmitic acid & 3.00 \\
Argania spinosa seed oil & 5.00 \\
Helianthus annuus hybrid oil & 5.00 \\
Sorbitan stearate & 2.90 \\
Q. pubescens extract & 2.65 \\
Polyglyceryl-4 laurate/Succinate (and) Aqua & $0.10-1.00$ \\
Sodium benzoate (and) Potassium sorbate & 0.80 \\
Citric acid & 0.40 \\
\hline${ }^{a}$ International Nomenclature of Cosmetic Ingredients, ${ }^{\text {b }}$ q.s.: quantity sufficient for.
\end{tabular}

\section{Conclusions}

In this article, the R\&D process adopted to develop a new objectivated cosmetic ingredient, from the plant sourcing to the actual ingredient formulation is presented in detail through the example of the development of promising natural anti-age ingredients based on $Q$. pubescens leaves extract.

Application of high throughput screening technologies to natural product samples accelerates considerably the discovery, development and use of natural cosmetic ingredients, but such a screening is still a long-term undertaking [56]. It was recently suggested that only five in every 100 genetic resources identified as being potentially of interest will ever end up in cosmetic and personal care formulas [57]. In fact, once the ingredient developed, it must pass all the efficacy, quality, shelf life and safety/tolerability (cytotoxicity, skin and ocular irritability) tests right throughout the development chain prior to be launched on the market. Only after this array of controls has been undertaken will a formulator consider using this ingredient in an actual finished-product formulation. Some researchers actually integrate the toxicology assessment directly into the cosmetic ingredient R\&D process to avoid an unpleasant discovery at the end of the process, which could lead to the restriction or even the abandonment of the ingredient's use due to toxicity concerns [58]. The vigilance about worldwide regulation compliance is guaranteed by the U.S. Food and Drug Administration (FDA). At the European level, the Scientific Committee on Consumer Safety (SCCS, replacing the former SCCNFP) establishes and regularly revises guidance notes that contain relevant information on the different aspects of testing and safety evaluation of cosmetic substances [59]. These notes must be adapted at each individual case, depending, for instance, on the nature of the ingredients entering the formulation, on the finished product's formulation itself, and the frequency and route of consumers' use of the product.

Hence, such a translation of laboratory research into commercial successes often takes time (up to several years) and manufacturers must back the right horse about market trends many years in advance.

Acknowledgments: H.P. is grateful to the CIFRE - Conventions Industrielles de Formation par la REcherche convention (ANRT JYTA) for her Ph.D. financing. The authors wish to thank Cécile Becquart for the development of the bioassays. 
Author Contributions: H.P., G.V.-D. and X.F. conceived and designed the experiments; H.P., A.L. and G.V.-D. sourced the plant material; H.P. and A.L. performed the experiments; H.P., P.B., S.A., A.L. and X.F. analyzed the data; H.P. and P.B. wrote the article; and all authors have equally contributed to its revision.

Conflicts of Interest: The authors declare no conflict of interest.

\section{References}

1. Lopaciuk, A.; Loboda, M. Global beauty industry trends in the 21st century. In Proceedings of the Management, Knowledge and Learning International Conference 2013, Zadar, Croatia, 19-21 June 2013; pp. 1079-1087.

2. Cosmetics Market by Category (Skin \& Sun Care Products, Hair Care Products, Deodorants, Makeup \& Color Cosmetics, Fragrances) and by Distribution Channel (General Departmental Store, Supermarkets, Drug Stores, Brand Outlets)—Global Opportunity Analysis and Industry Forecast, 2014-2022. Available online: https: / / www.alliedmarketresearch.com/cosmetics-market (accessed on 17 November 2017).

3. Beauty Survey 2017: Key Insights and System Update. Available online: http:/ / go.euromonitor.com/WP171024-BeautyandPersonalCareSurvey.html (accessed on 17 November 2017).

4. Official Journal of the European Union. Commission Regulation (EU) No 655/2013 of 10 July 2013 Laying Down Common Criteria for the Justification of Claims Used in Relation to Cosmetic Products. 2013. Available online: http:/ / ec.europa.eu/consumers/sectors/cosmetics/files/pdf/guide_reg_claims_en.pdf (accessed on 17 November 2017).

5. Whitehouse, L. Proving Claims to Maximise on Beauty Trends. Available online: https://www.cosmeticsdesigneurope.com/Article/2017/06/30/Proving-claims-to-maximise-on-beauty-trends (accessed on 1 December 2017).

6. Natural and Organic Beauty: Market Size Worldwide 2016-2024. Available online: https:/ /www.statista. $\mathrm{com} /$ statistics/750779/natural-organic-beauty-market-worldwide/ (accessed on 17 November 2017).

7. Cosmetic Ingredients: Global Market Size by Category 2015-2020. Available online: https://www. statista.com/statistics/627730/market-size-of-cosmetic-ingredients-worldwide-by-category/ (accessed on 17 November 2017).

8. Cosmetic Ingredients: Global Market Size 2015-2020. Available online: https:/ /www.statista.com/statistics/ 627786/market-size-of-cosmetic-ingredients-worldwide/ (accessed on 17 November 2017).

9. Wynberg, R.P.; Laird, S.A. Access and benefit-sharing: Key points for policy-makers. The cosmetics industry. People Plants Int. 2015. Available online: https:/ / www.researchgate.net/publication/303286830_ Access_and_Benefit_Sharing_Key_Points_for_Policy-_Makers_-_The_Cosmetics_Industry (accessed on 22 November 2017).

10. Chemat, F.; Strube, J. Green Extraction of Natural Products: Theory and Practice; John Wiley \& Sons: Hoboken, NJ, USA, 2015; ISBN 978-3-527-33653-1.

11. Mukherjee, P.K.; Maity, N.; Nema, N.K.; Sarkar, B.K. Bioactive compounds from natural resources against skin aging. Phytomedicine 2011, 19, 64-73. [CrossRef] [PubMed]

12. Krutmann, J.; Liu, W.; Li, L.; Pan, X.; Crawford, M.; Sore, G.; Seite, S. Pollution and skin: From epidemiological and mechanistic studies to clinical implications. J. Dermatol. Sci. 2014, 76, 163-168. [CrossRef] [PubMed]

13. Pan, T.-L.; Wang, P.-W.; Aljuffali, I.A.; Huang, C.-T.; Lee, C.-W.; Fang, J.-Y. The impact of urban particulate pollution on skin barrier function and the subsequent drug absorption. J. Dermatol. Sci. 2015, 78, 51-60. [CrossRef] [PubMed]

14. Plainfossé, H.; Burger, P.; Michel, T.; Landreau, A.; Fernandez, X. Actifs cosmétiques pour la réparation cutanée. Tech. Ing. 2017, J3002. Available online: https:/ / www.techniques-ingenieur.fr/base-documentaire/ procedes-chimie-bio-agro-th2 / cosmetiques-42634210/actifs-cosmetiques-pour-la-reparation-cutaneej3002/ (accessed on 25 November 2017).

15. Ganceviciene, R.; Liakou, A.I.; Theodoridis, A.; Makrantonaki, E.; Zouboulis, C.C. Skin anti-aging strategies. Dermatoendocrinol 2012, 4, 308-319. [CrossRef] [PubMed]

16. Life Expectancy. Available online: http://www.who.int/gho/mortality_burden_disease/life_tables/ situation_trends_text/en/ (accessed on 22 November 2017).

17. Osbourn, A.E.; Lanzotti, V. Plant-Derived Natural Products: Synthesis, Function, and Application; Springer Science \& Business Media: Berlin, Germany, 2009; ISBN 978-0-387-85498-4. 
18. Médail, F.; Quézel, P. Biodiversity hotspots in the Mediterranean Basin: Setting global conservation priorities. Conserv. Biol. 1999, 13, 1510-1513. [CrossRef]

19. Médail, F.; Quezel, P. Hot-spots analysis for conservation of plant biodiversity in the Mediterranean basin. Ann. Mo. Bot. Gard. 1997, 84, 112-127. [CrossRef]

20. Quercus pubescens Willd. Available online: https://npgsweb.ars-grin.gov/gringlobal/taxonomydetail.aspx? id=30735 (accessed on 23 November 2017).

21. Apostol, E.N.; Dinu, C.G.; Apostol, B.; Ciuvăț, A.L.; Lorent, A.; Pleșca, I.; Postolache, D.; Leca, S.; Enescu, C.M. Importance of pubescent oak (Quercus pubescens Willd.) for Romanian forests in the context of climate change. Rev. Silvic. Și Cinegetică 2016, 21, 29-33.

22. Quercus pubescens-EUFORGEN European Forest Genetic Resources Program. Available online: http: / / www.euforgen.org/species/quercus-pubescens / (accessed on 15 November 2017).

23. Gallé, A.; Haldimann, P.; Feller, U. Photosynthetic performance and water relations in young pubescent oak (Quercus pubescens) trees during drought stress and recovery. New Phytol. 2007, 174, 799-810. [CrossRef] [PubMed]

24. CosIng-Cosmetics-GROWTH_European Commission. Available online: http:/ / ec.europa.eu/growth/ tools-databases/cosing/index.cfm?fuseaction=search.advanced (accessed on 23 November 2017).

25. Lee, M.W.; Kim, H.H.; Kim, D.H. Composition for anti-wrinkling comprising fractions from leaves of Quercus mongolica. International Patent Application No. KR101483872, 19 January 2015. Available online: https: / / worldwide.espacenet.com / publicationDetails / biblio?FT=D\&date=20150119\&DB=EPODOC\& locale=fr_EP \&CC $=\mathrm{KR} \& N R=101483872 \mathrm{~B} 1 \& \mathrm{KC}=\mathrm{B} 1 \& \mathrm{ND}=6$ (accessed on 27 November 2017).

26. Yang, K.W.; Kim, J.M.; Kim, K.M.; Ko, H.N.; Lee, M.Y.; Lee, Y.B. Composition for improving wrinkles using Quercus glauca branch extracts. International Patent Application No. KR20140137837, 3 December 2014. Available online: https:/ / worldwide.espacenet.com/publicationDetails / biblio?FT=D\&date=20141203\& $\mathrm{DB}=\mathrm{EPODOC} \&$ locale $=\mathrm{fr} \_\mathrm{EP} \& \mathrm{CC}=\mathrm{KR} \& \mathrm{NR}=20140137837 \mathrm{~A} \& \mathrm{KC}=\mathrm{A} \& \mathrm{ND}=5$ (accessed on 27 November 2017).

27. Charlois, S.; Riboulet, J.-M.; Bregou, M. Active Ingredient Based on an Oak Plant Extract with Anti-Skin Aging Effect and Cosmetic Composition Comprising Same. International Patent Application No. PCT/FR2014/052962, 28 May 2015. Available online: https: / / worldwide.espacenet.com/publicationDetails / biblio?FT=D\&date=20150528\&DB=EPODOC\&locale=fr_EP\&CC $=$ WO\&NR=2015075377A1\&KC $=$ A1 \& $\mathrm{ND}=5$ (accessed on 27 November 2017).

28. Favre, E. Cosmetic Composition Containing an Anti-Oxidant Agent Containing Oak and Aniseed Extracts. International Patent Application No. PCT/FR2008/051742, 23 April 2009. Available online: http:/ /www. google.ca/patents/WO2009050398A2 (accessed on 30 November 2017).

29. McLafferty, F.W.; Stauffer, D.B. The Wiley/NBS Registry of Mass Spectral Data; Wiley: New York, NY, USA, 1989; ISBN 978-0-471-62886-6.

30. Boelens Aroma Chemical Information Service. BACIS ESO 2000, the Complete Database of Essential Oils; Leffingwell \& Associates: Canton, GA, USA, 1999.

31. Brand-Williams, W.; Cuvelier, M.E.; Berset, C. Use of a free radical method to evaluate antioxidant activity. LWT Food Sci. Technol. 1995, 28, 25-30. [CrossRef]

32. Koleva, I.I.; van Beek, T.A.; Linssen, J.P.H.; de Groot, A.; Evstatieva, L.N. Screening of plant extracts for antioxidant activity: A comparative study on three testing methods. Phytochem. Anal. PCA 2002, 13, 8-17. [CrossRef] [PubMed]

33. Burger, P.; Landreau, A.; Azoulay, S.; Michel, T.; Fernandez, X. Skin whitening cosmetics: Feedback and challenges in the development of natural skin lighteners. Cosmetics 2016, 3, 36. [CrossRef]

34. Lu, W.; Zhao, X.; Xu, Z.; Dong, N.; Zou, S.; Shen, X.; Huang, J. Development of a new colorimetric assay for lipoxygenase activity. Anal. Biochem. 2013, 441, 162-168. [CrossRef] [PubMed]

35. Debelle, L.; Tamburro, A.M. Elastin: Molecular description and function. Int. J. Biochem. Cell Biol. 1999, 31, 261-272. [CrossRef]

36. Papakonstantinou, E.; Roth, M.; Karakiulakis, G. Hyaluronic acid: A key molecule in skin aging. Dermatoendocrinol 2012, 4, 253-258. [CrossRef] [PubMed]

37. Baumann, L. Skin ageing and its treatment. J. Pathol. 2007, 211, 241-251. [CrossRef] [PubMed]

38. Roy, A.; Sahu, R.K.; Matlam, M.; Deshmukh, V.K.; Dwivedi, J.; Jha, A.K. In vitro techniques to assess the proficiency of skin care cosmetic formulations. Pharmacogn. Rev. 2013, 7, 97-106. [CrossRef] [PubMed] 
39. Singleton, V.L.; Rossi, J.A. Colorimetry of total phenolics with phosphomolybdic-phosphotungstic acid reagents. Am. J. Enol. Vitic. 1965, 16, 144-158.

40. CIE. Colorimetry_Part 4: CIE 1976 L*$^{*} B^{*}$ Colour Space; CIE DS 014-4.3/E:2007; CIE Central Bureau: Vienna, Austria, 2007.

41. Rhein, L.D.; Schlossman, M.; O'Lenick, A.; Somasundaran, P. Surfactants in Personal Care Products and Decorative Cosmetics, 3rd ed.; CRC Press: Boca Raton, FL, USA, 2006; ISBN 978-1-4200-1612-3.

42. ViewSonic. Technical Introduction. Delta E $\leq 2$ Colour Accuracy. Available online: https: / www.viewsonic. com/uk/products/lcd/pdf/ti_delta_E.pdf (accessed on 12 December 2017).

43. Engel, R.; Gülz, P.-G.; Herrmann, T.; Nahrstedt, A. Glandular trichomes and the volatiles obtained by steam distillation of Quercus robur leaves. Z. Für Naturforschung C 1993, 48, 736-744.

44. Jordão, A.M.; Ricardo-da-Silva, J.M.; Laureano, O.; Adams, A.; Demyttenaere, J.; Verhé, R.; De Kimpe, N. Volatile composition analysis by solid-phase microextraction applied to oak wood used in cooperage (Quercus pyrenaica and Quercus petraea): Effect of botanical species and toasting process. J. Wood Sci. 2006, 52, 514-521. [CrossRef]

45. Palma-Fleming, H.A.; Kepner, R.E. Volatile components of California live oak, Quercus agrifolia. Phytochemistry 1983, 22, 1503-1505. [CrossRef]

46. Kameoka, H.; Aso, Y.; Tsujino, H. Constituents of essential oil of leaves of Quercus dentata Thunb. J. Agric. Chem. Soc. Jpn. 1983, 57, 135-138.

47. Mosedale, J.R.; Feuillat, F.; Baumes, R.; Dupouey, J.-L.; Puech, J.-L. Variability of wood extractives among Quercus robur and Quercus petraea trees from mixed stands and their relation to wood anatomy and leaf morphology. Can. J. For. Res. 1998, 28, 994-1006. [CrossRef]

48. Fengel, D.; Wegener, G. Wood: Chemistry, Ultrastructure, Reactions; Walter de Gruyter: Berlin, Germany, 1983.

49. Rocha, S.M.; Coimbra, M.A.; Delgadillo, I. Occurrence of furfuraldehydes during the processing of Quercus suber L. cork. Simultaneous determination of furfural, 5-hydroxymethylfurfural and 5-methylfurfural and their relation with cork polysaccharides. Carbohydr. Polym. 2004, 56, 287-293. [CrossRef]

50. Plazonić, A.; Mornar, A.; Maleš, Ž.; Kujundžić, N. Phenolic content and antioxidant activities of Burr Parsley (Caucalis platycarpos L.). Molecules 2013, 18, 8666-8681. [CrossRef] [PubMed]

51. Da Silva, J.F.M.; de Souza, M.C.; Matta, S.R.; de Andrade, M.R.; Vidal, F.V.N. Correlation analysis between phenolic levels of Brazilian propolis extracts and their antimicrobial and antioxidant activities. Food Chem. 2006, 99, 431-435. [CrossRef]

52. Pientaweeratch, S.; Panapisal, V.; Tansirikongkol, A. Antioxidant, anti-collagenase and anti-elastase activities of Phyllanthus emblica, Manilkara zapota and silymarin: An in vitro comparative study for anti-aging applications. Pharm. Biol. 2016, 54, 1865-1872. [CrossRef] [PubMed]

53. Justino, G.C.; Correia, C.F.; Mira, L.; Borges Dos Santos, R.M.; Martinho Simões, J.A.; Silva, A.M.; Santos, C.; Gigante, B. Antioxidant activity of a catechol derived from abietic acid. J. Agric. Food Chem. 2006, 54, 342-348. [CrossRef] [PubMed]

54. Kolayli, S.; Sahin, H.; Can, Z.; Yildiz, O.; Sahin, K. Honey shows potent inhibitory activity against the bovine testes hyaluronidase. J. Enzyme Inhib. Med. Chem. 2016, 31, 599-602. [CrossRef] [PubMed]

55. Fernandez, X.; Merck, F.; Kerdudo, A. Conservateurs pour les cosmétiques-Généralités et conservateursantimicrobiens. Tech. Ing. 2012, J2284. Available online: https:/ /www.techniques-ingenieur.fr/basedocumentaire/procedes-chimie-bio-agro-th2/cosmetiques-42634210/conservateurs-pour-cosmetiques-j2284/ (accessed on 23 November 2017).

56. Kerdudo, A.; Burger, P.; Merck, F.; Dingas, A.; Rolland, Y.; Michel, T.; Fernandez, X. Development of a natural ingredient-Natural preservative: A case study. Comptes Rendus Chim. 2016, 19, 1077-1089. [CrossRef]

57. d'Enfert, V. The Nagoya Protocol imposes new rules. Expr. Cosmétique 2013, 24, 40-42.

58. Salminen, W.F. Integrating toxicology into cosmetic ingredient research and development. Int. J. Cosmet. Sci. 2002, 24, 217-224. [CrossRef] [PubMed]

59. SCCS. The SCCS Notes of Guidance for the Testing of Cosmetic Ingredients and Their Safety Evaluation, 9th Revision; SCCS: Brussels, Belgium, 2016.

(C) 2018 by the authors. Licensee MDPI, Basel, Switzerland. This article is an open access article distributed under the terms and conditions of the Creative Commons Attribution (CC BY) license (http:/ / creativecommons.org/licenses/by/4.0/). 